\title{
EMOÇÃO E TELENOVELA: UM ESTUDO DAS ESTRATÉGIAS DE PATEMIZAÇÃO EM O ASTRO
}

\author{
Leonardo Coelho Corrêa-Rosado* \\ Universidade Federal de Minas Gerais \\ Faculdade de Letras \\ Belo Horizonte, MG, Brasil
}

Mônica Santos de Souza Melo*

Universidade Federal de Viçosa

Departamento de Letras

Viçosa, MG, Brasil

\begin{abstract}
Resumo: O presente trabalho objetiva descrever e analisar as estratégias de patemização em um plot, isto é, em uma trajetória de ação narrativa, na telenovela $\mathrm{O}$ Astro, a partir de 10 sequências audiovisuais que representam este plot. A novela foi exibida pela Rede Globo entre 12 de julho e 28 de outubro de 2011 no horário das 23 horas. A pesquisa foi realizada a partir do arcabouço teórico-metodológico da Teoria Semiolinguística (CHARAUDEAU, 1983, 1992, 1995, 2006). Para a análise da patemização, estratificamos o objeto de estudo em dois estratos: verbal e visual-filmico. Os resultados evidenciaram que, como estratégia discursiva, a patemização toca o plano da captação: a instância midiática deseja emocionar o telespectador com o intuito de mantê-lo cativo durante a exibição da telenovela.
\end{abstract}

Palavras-chave: Semiolinguística. Telenovela. Emoção.

\section{INTRODUÇÃO}

Assistir telenovela é um hábito muito comum na vida de muitos brasileiros. Diante da TV, parecemos compartilhar as mesmas emoções que os personagens vivem ao longo da história. Rimos e choramos com eles; sofremos quando as coisas que lhes ocorrem não parecem ir muito bem; encaramo-los como pessoas próximas, quase membros da família. Enfim, neste espetáculo televisivo que parece representar a vida, a emoção joga um papel importante. As telenovelas são, então, construídas para fazer rir e chorar e, no fim das contas, acabam fazendo exatamente isso: emocionando os telespectadores.

\footnotetext{
* Doutorando do Programa de Pós-Graduação em Estudos Linguísticos. Bolsista CAPES/DS. E-mail: timtimcorre@hotmail.com

** Professora Associada II. Doutora em Estudos Linguísticos pela UFMG. E-mail: monicassmelo@yahoo.com.br 
No entanto, como a emoção, do ponto de vista discursivo, funciona na telenovela? De que estratégias o enunciador (como discurso, a telenovela pressupõe um sujeito que a enuncia) lança mão para emocionar o telespectador? Como os signos são organizados para atingir esta finalidade comunicativa? Estas são algumas perguntas que pretendemos responder com este artigo.

Assim, o presente trabalho é um estudo da emoção na telenovela. Para tal selecionamos a telenovela $O$ Astro, exibida pela Rede Globo de televisão em 2011 no horário das $23 \mathrm{~h}$. Nosso objetivo é compreender o modo como a emoção opera no discurso, descrevendo e analisando as estratégias de patemização em um plot da telenovela selecionada, a partir de 10 sequências audiovisuais que o representam.

Este estudo está baseado no arcabouço teórico-metodológico fornecido pela Teoria Semiolinguística (TS) de Patrick Charaudeau, mais precisamente no conceito de patemização definido pela teoria.

\section{DISCURSO, EMOÇÃO E SEMIOLINGUÍSTICA: A PATEMIZAÇÃO}

Segundo Charaudeau (2000, 2008, 2010), no quadro da Teoria Semiolinguística, a emoção deve ser encarada em uma perspectiva de efeito discursivo engendrado pelo discurso ou ato de linguagem. Nesse sentido, a emoção não se constitui como uma manifestação do sujeito, muito menos como o sintoma do comportamento coletivo, mas como um signo discursivo portador daquilo que pode advir ao sujeito pelo fato deste sujeito reconhecê-lo, através dos discursos de representação socialmente codificados, como uma figura sobre a qual se apoia o discurso.

Em outras palavras, a proposta de Charaudeau (2000) é estudar a emoção como um efeito visado (e não produzido) pelo sujeito enunciador, isto é, como um efeito que este pretende ver atingido por meio de sua encenação discursiva.

De forma a delimitar o escopo do estudo da emoção no discurso, Charaudeau (2010) denomina tais efeitos de efeitos patêmicos, justificando que:

[é] a razão pela qual prefiro os termos "pathos", "patêmico" e "patemização" em lugar de emoção. Isso me permite, por um lado, inserir a análise do discurso das emoções na filiação da retórica que desde Aristóteles trata os discursos em uma perspectiva de visada e de efeitos [...], por outro lado, me permite dissociar a análise do discurso, caso seja necessário, da psicologia e da sociologia. (CHARAUDEAU, 2010, p. 35).

Sendo, então, uma categoria de efeito, o tratamento discursivo das emoções se dá a partir de três aspectos:

- as emoções são de ordem intencional, uma vez que elas se experimentam no sujeito como a representação de um objeto em direção ao qual ele se move, ou que ele tenta combater. Elas se manifestam como um agir para chegar a um objetivo, sendo desencadeadas por algo que é da ordem do desejo;

- as emoções estão ligadas aos saberes de crenças, visto que estão sujeitas a julgamentos que se apoiam nas crenças partilhadas por um grupo social, cujo respeito às normas ou não acarretaria uma sanção social. Assim, as emoções são 
estados mentais que se apoiam sobre os saberes de crenças, saberes esses estruturados ao redor de valores polarizados e dependentes da subjetividade do sujeito, uma vez que elas existem em razão dessa subjetividade;

- as emoções se inscrevem em uma problemática de representação psicossocial pelo fato de serem estados mentais intencionais que se apoiam sobre saberes de crença. Dessa forma, as emoções são representações patêmicas que descrevem uma situação a propósito da qual um julgamento de valor, coletivamente partilhado e instituído em uma norma social, envolve um actante, que é um ser beneficiário ou vítima e ao qual o sujeito da representação se encontra ligado. É, nesse sentido que Charaudeau (2000) fala de tópica das emoções.

Assim, o estudo da patemização toca na questão de que a construção discursiva do sentido é uma encenação dos efeitos visados que depende das inferências produzidas pelos parceiros do ato de linguagem, sendo que essas inferências dependem dos conhecimentos (saberes) da situação de comunicação. Logo, a organização do universo patêmico está calcada na situação social e sociocultural na qual a troca comunicativa se inscreve.

A patemização é, então, o resultado de um jogo entre as instruções contratuais e as liberdades enunciativas, o que pressupõe condições para a sua realização. Charaudeau (2000) lista três condições para a organização desse tipo de efeito de sentido no discurso:

a) Dispositivo comunicativo: os componentes do contrato de comunicação, sobretudo a finalidade e a identidade, devem predispor ao efeito patêmico, pois, como vimos, é a situação de comunicação que emana instruções discursivas para o desenvolvimento dos processos linguageiro do ato de influência;

b) Campo temático: o campo temático em que o ato de linguagem se apoia deve prever um universo de patemização e produzir uma certa organização das tópicas (imaginários sociodiscursivos) para produzir um efeito patêmico;

c) Espaço de estratégia: a instância enunciativa, ou o sujeito enunciador, deve, no interior do processo de dramatização, utilizar uma encenação discursiva com finalidade patemizante, isto é, as estratégias devem ser organizadas para produzir efeitos patêmicos.

No discurso, o efeito patêmico pode ser obtido de forma explícita e direta: o sujeito enunciador (EUe) emprega palavras que remetem a um universo emocional, de tonalidade patêmica; ou pode ser obtido de forma implícita e indireta: o EUe emprega palavras que, aparentemente, são neutras do ponto de vista da emoção.

\section{A TELENOVELA O ASTRO: CONHECENDO O CORPUS}

A telenovela $O$ Astro, exibida pela Rede Globo de Televisão entre os dias 12 de julho e 28 de outubro de 2011, é um remake, escrito por Alcides Nogueira e Geraldo Carneiro, da obra de Janete Clair $O$ Astro, também exibida pela mesma emissora, de 6 de dezembro de 1977 a 8 de julho de 1978. O remake de 64 capítulos foi ao ar de terça a sexta-feira na faixa das $23 \mathrm{~h}$, inaugurando, com isso, um novo horário para a exibição de telenovelas no âmbito da grade de programação da Rede Globo. 
Uma das tramas do remake de $O$ Astro é o misterioso assassinato de Salomão Hayalla, um empresário de grandes posses, muito materialista e presidente do Grupo Hayalla. $\mathrm{O}$ assassinato, ocorrido no capítulo 15, gerou um grande suspense ao longo da exibição dos demais 49 capítulos da telenovela, pois as identidades dos assassinos só foram reveladas no último capítulo.

A trama resume-se da seguinte maneira: Salomão Hayalla (Daniel Filho) dedicou sua vida a angariar dinheiro e a aumentar sua fortuna. Seu jeito controlador, prepotente e arrogante despertou a ira dos irmãos, das cunhadas e principalmente da esposa, Clô Hayalla (Regina Duarte). Ao ser questionado publicamente pelo filho Márcio (Thiago Fragoso), Salomão decide interná-lo em uma clínica de doentes mentais. Indignada com a atitude desumana do marido para com o filho, Clô começa a planejar a morte dele. Em uma festa na mansão dos Hayallas, Clô empurra o marido pela janela e efetiva seu plano. A cena deixa oculta a verdadeira identidade do assassino, revelada somente no último capítulo. A trama se desenvolve de modo a levantar no telespectador a pergunta "quem matou Salomão Hayalla?". Uma lista de suspeitos é criada no próprio desenrolar da telenovela.

A morte de Salomão, entretanto, não é somente conduzida por sua esposa, Clô. Outros personagens entram em jogo como auxiliares, sem, entretanto, configurar uma ação planejada pelo grupo. Cada um tenta matar Salomão por razões próprias que, por acaso do "destino", acabam convergindo e configurando o assassinato. O mordomo Inácio (Paschoal da Conceição), indignado com o jeito cruel do patrão, troca os antiácidos de Salomão por um veneno poderoso, o polônio. O irmão, Youssef Hayalla (José Rubens Chachá), a mando de sua esposa Nádia (Vera Zimermann), dá uma coronhada na cabeça de Salomão com uma pistola prata oferecida pela esposa. Já Clô empurra o marido pela janela, completando o quadro.

O processo de investigação do assassinato é conduzido pelos inspetores da Delegacia de Homicídios, Estáquio (Daniel Dantas) e Elizabeth (Úrsula Corona). No capítulo 64 (último capítulo), os inspetores se reúnem na sala-de-estar da mansão dos Hayalla e revelam, não só para as personagens, mas também para o telespectador, os assassinos de Salomão.

O nosso corpus foi constituído por 10 sequências audiovisuais que representam a trama descrita acima e que denominamos “Quem matou Salomão Hayalla?”. A trama em questão se materializa, basicamente, em sequências que evidenciam as causas da morte (intrigas familiares), a morte e a revelação do(s) assassino(s). A tabela 1 mostra a relação de sequências por capítulo, sua denominação em nosso corpus e sua duração.

Após a seleção das sequências, realizamos a transcrição audiovisual de cada uma delas, seguindo as orientações gerais propostas por Melo (2003). De acordo com esta pesquisadora, a transcrição audiovisual deve se realizar a partir de dois principais elementos:

a) reprodução do estrato verbal, isto é, dos enunciados orais ou escritos que se apresentam no interior das sequências;

b) congelamento e reprodução das imagens quadro a quadro, a partir de processos digitais e composição dos videogramas. 
Tabela 1 - Sequências que constituem o corpus de pesquisa considerando suas denominações ao longo do trabalho e sua duração (parcial e total)

\begin{tabular}{|c|c|c|c|}
\hline CAPÍTULOS & DENOMINAÇÃO & \multicolumn{2}{|c|}{ DURAÇÃO } \\
\hline Capítulo 1 & CAP01SEQ01 & 00:04:10 & 00:04:10 \\
\hline \multirow[t]{3}{*}{ Capítulo 2} & CAP02SEQ02 & 00:06:49 & 00:06:49 \\
\hline & CAP02SEQ03 & 00:01:35 & $00: 01: 35$ \\
\hline & CAP02SEQ04 & 00:01:24 & $00: 01: 24$ \\
\hline \multirow[t]{2}{*}{ Capítulo 3} & CAP03SEQ05 & $00: 05: 10$ & $00: 05: 10$ \\
\hline & CAP03SEQ06 & 00:00:58 & 00:00:58 \\
\hline \multirow{6}{*}{ Capítulo 15} & CAP15SEQ07 & $00: 00: 30$ & 00:00:30 \\
\hline & CAP15SEQ08 & $00: 00: 27$ & $00: 00: 27$ \\
\hline & CAP15SEQ09 - Parte 1 & 00:00:52 & \multirow[t]{4}{*}{ 00:16:08 } \\
\hline & CAP15SEQ09-Parte 2 & $00: 03: 45$ & \\
\hline & CAP15SEQ09 - Parte 3 & $00: 06: 22$ & \\
\hline & CAP15SEQ09 - Parte 4 & 00:05:09 & \\
\hline \multirow[t]{2}{*}{ Capítulo 64} & CAP64SEQ10 - Parte 1 & 00:01:54 & \multirow[t]{2}{*}{$00: 16: 43$} \\
\hline & CAP64SEQ10 - Parte 2 & $00: 14: 49$ & \\
\hline TOTAL & & & $00: 53: 54$ \\
\hline
\end{tabular}

A decomposição das 10 sequências audiovisuais do nosso corpus totalizou 2265 videogramas. Tal decomposição se justifica pelo fato de adotarmos como procedimento metodológico a estratificação do objeto em um nível de análise autônoma das substâncias semiológicas tal como propõe Charaudeau (1995). O referido pesquisador argumenta que, no caso de textos sincréticos - como é a telenovela -, a análise deve ser conduzida de forma a contemplar separadamente cada substância semiológica envolvida na configuração do ato de linguagem estudado. Este tipo de procedimento possibilita a descoberta das unidades próprias de cada estrato e o modo de agenciamento delas no discurso. Charaudeau (1995) complementa que, só em um segundo momento, as relações entre estratos devem ser contempladas, de forma a interpretar o todo do ato de linguagem em análise.

Desse modo, a decomposição em videogramas permitiu-nos compreender melhor o funcionamento da patemização no estrato visual-fílmico. Além do mais, a totalidade de videogramas encontrada foi considerada para a confecção dos gráficos apresentados ao longo do trabalho. A tabela 2 a seguir mostra o número de videogramas levantados por sequência.

Ressaltamos que a coleta dos capítulos da telenovela foi realizada durante todo o período de exibição de $O$ Astro, a partir de gravações digitais, utilizando um hardware e software adequados. Em termos de hardware, valemo-nos de uma placa de captura de vídeo do tipo TV Turner. Em relação ao software, utilizamos o disponibilizado pela placa, o ENUTV-3. 
Tabela 2 - Relação entre sequências e decomposição em videogramas

\begin{tabular}{ccc}
\hline Sequência & Duração & Número de Videogramas \\
\hline CAP01SEQ01 & $00: 04: 10$ & $\mathbf{2 5 8}$ \\
CAP02SEQ02 & $00: 06: 49$ & $\mathbf{2 6 3}$ \\
CAP02SEQ03 & $00: 01: 35$ & $\mathbf{8 6}$ \\
CAP02SEQ04 & $00: 01: 24$ & $\mathbf{7 8}$ \\
CAP03SEQ05 & $00: 05: 10$ & $\mathbf{2 1 9}$ \\
CAP03SEQ06 & $00: 00: 58$ & $\mathbf{4 7}$ \\
CAP15SEQ07 & $00: 00: 30$ & $\mathbf{2 2}$ \\
CAP15SEQ08 & $00: 00: 27$ & $\mathbf{2 7}$ \\
CAP15SEQ09 & $00: 16: 08$ & $\mathbf{6 4 6}$ \\
CAP64SEQ10 & $00: 16: 43$ & $\mathbf{6 1 9}$ \\
\hline Total & $\mathbf{0 0 : 5 3 : 5 4}$ & $\mathbf{2 2 6 5}$ \\
\hline
\end{tabular}

4 CONDIÇÕES DE PATEMIZAÇÃO

Como já mencionamos, as condições de patemização correspondem aos requisitos necessários para que os efeitos patêmicos se realizem no interior de um ato de linguagem. Elas são, portanto, elementos que garantem que um determinado ato de linguagem produza efeitos de sentido ligados à suscitação de emoções no destinatário, ou seja, a efeitos de sentidos que levem, em uma perspectiva de influência, o destinatário a um fazer-sentir - uma visada emocional, nas palavras de Lochard e Soulages (1998).

Nas subseções que seguem apresentaremos os resultados encontrados na análise de nosso corpus no que tange às três condições de patemização arroladas por Charaudeau (2000), dispositivo enunciativo, campo temático e estratégias.

\subsection{DISPOSITIVO COMUNICATIVO}

Em um trabalho anterior sobre o qual abordamos a telenovela das $23 \mathrm{~h}$ em termos de sua configuração genérica ${ }^{1}$, apontamos que o referido gênero ${ }^{2}$ tem como finalidade contar uma história, por meio de diálogos e imagens, para os telespectadores, com vistas a entretê-los. Nesse sentido, tal finalidade organiza-se por propor ao telespectador uma satisfação hedônica, ou seja, a finalidade é faire-plaisir (fazer-agradar) em função da história que é contada por meio das imagens e dos diálogos.

\footnotetext{
${ }^{1}$ Estamos nos referindo ao nosso trabalho publicado neste mesmo periódico no volume 15, número 2, de 2015, cujo título é "A telenovela das 23h: uma descrição do gênero a partir da teoria semiolinguística".

${ }^{2}$ Partindo do postulado bakhtiniano de que é preciso certas referências para comunicar, Charaudeau (2004) entende que os gêneros estão ancorados na dimensão social da linguagem, sem esquecer de suas outras dimensões, a discursiva e a formal. Com isso, ele os denomina gêneros situacionais, na medida em que as características do discurso dependem essencialmente de suas condições de produção em determinadas situações, isto é, dos dados do contrato comunicacional que modela a situação de troca verbal.
} 
Esse fazer-agradar permite atualizar uma visada ${ }^{3}$ emocional que se define por um projeto de fala que procura suscitar no destinatário um conjunto de emoções e afeições, fazendo dele um sujeito "que sente". Suscintamente, esta visada pode ser compreendida da seguinte maneira: eu quer "agradar" (fazer-agradar) e tem condições para tal, já que possui meios de suscitar emoções e afeições; tu se encontra em posição de "ser agradado" e de "sentir" as emoções suscitadas.

Assim, a finalidade comunicativa do gênero engendra uma visada emocional em seu contrato comunicacional, garantindo, com isso, a predisposição a efeitos patêmicos no que concerne ao seu dispositivo comunicativo.

Logo, as sequências audiovisuais que constituem o nosso corpus, por serem fragmentos do ato de linguagem telenovelístico, cumprem, todas elas, essa primeira condição de patemização. Em outras palavras, as sequências possuem um dispositivo comunicativo que predispõe o destinatário a efeitos patêmicos.

Além do contrato comunicacional, o dispositivo enunciativo de ficção ${ }^{4}$ dispositivo esse que a telenovela assume para encenar suas estratégias e mobilizar os recursos linguageiros do dispositivo televisivo - também permite a predisposição a efeitos patêmicos no interior da encenação discursiva. Tal dispositivo propõe, por um lado, uma clausura diegética ao construir uma realidade espaço-temporal independente reportada a um Eu origem fictícia (o narrador) e, por outro lado, exige do interpretante um esforço cooperativo para acreditar na história apresentada pela tela da TV.

Desse modo, este dispositivo enunciativo coloca o telespectador (o nosso sujeito interpretante, ou TUi) na posição de um observador-testemunha, suscitando de sua parte uma atitude de projeção-identificação. $O$ dispositivo de ficção predispõe, então, o telespectador (TUi) a ressentir os efeitos visados pela instância midiática, já que tal sujeito pode se identificar com o estado emocional de alguma figura actorial do mundo diegético criado pelo dispositivo.

Portanto, no que concerne à primeira condição de patemização, tanto o contrato que sobredetermina o gênero da telenovela $O$ Astro, quanto o dispositivo enunciativo de ficção utilizado para realizar a encenação discursiva do ato de linguagem em estudo possibilitam a predisposição a efeitos patêmicos, uma vez que as condições contratuais da troca possuem uma finalidade patemizante, materializada pela visada emocional, e a atitude de projeção-identificação instaurada pelo dispositivo enunciativo de ficção garante que o telespectador possa ressentir os efeitos emocionais visados.

\footnotetext{
${ }^{3}$ Charaudeau (2004, p. 23) define visada como sendo uma intencionalidade psico-sócio-discursiva que determina a expectativa do ato de linguagem, correspondendo, com isso, a uma atitude enunciativa de base definida tanto pela intenção comunicativa do sujeito comunicante, quanto pela identidade que ele atribui ao sujeito interpretante.

${ }^{4}$ De acordo com Lochard e Soulages (1998), o dispositivo enunciativo de midiatização corresponde a uma mecânica discursiva que sobredetermina os programas televisuais, mobilizando procedimentos linguageiros característicos e também revelando estratégias discursivas específicas. Assim, tal dispositivo rege o posicionamento do enunciador e do telespectador, já que ele corresponde ao suporte da discursivização (mise en discours).
} 
Nosso corpus é constituído de sequências audiovisuais que representam um determinado plot (trama narrativa) da história da telenovela $O$ Astro. O plot escolhido para esse trabalho foi denominado "Quem matou Salomão Hayalla?", uma vez que nele as ações centrais correspondem ao assassinato do empresário, à investigação desse assassinato e, consequentemente, à revelação dos assassinos da figura actorial/personagem Salomão Hayalla.

Nesse sentido, se a condição do campo temático deve prever a existência de um universo de patemização, o nosso corpus, por representar o plot em questão, realiza, numa perspectiva macro, essa segunda condição de patemização. Isso ocorre pelo fato de o plot selecionado propor uma organização de tópicas susceptíveis de produzir esse tipo de efeito. Isto é, o plot "Quem matou Salomão Hayalla?" suscita certos universos temáticos, tais como aqueles ligados à questão do assassinato, da morte, da investigação policial, que acionam tópicas ligadas à emoção.

As tópicas que estruturam o universo de patemização de um determinado ato de linguagem correspondem, em Charaudeau (2000), a certos tipos de imaginários sociodiscursivos compartilhados por um dado grupo social. Para Charaudeau (2007), os imaginários sociodiscursivos constituem-se em um modo de apreensão do mundo, que está calcado nos saberes que os membros de um determinado grupo compartilham entre si. Desse modo, os imaginários são uma construção coletiva que, ao mesmo tempo, identifica esse grupo, cria-lhe valores e justifica as ações que os indivíduos realizam. Eles possibilitam dar significação à realidade, já que toda produção discursiva os engendra no processo de simbolização do mundo.

Nesse sentido, o universo temático de nosso corpus é patêmico na medida em que os imaginários sociodiscursivos que balizam tal universo são tidos como tal. A ideia de assassinato (e, por conseguinte, a de morte) suscita tópicas variadas como a da dor, a da angústia e a da repulsa, no âmbito de nossa sociedade. Logo, o nosso corpus, ao lidar com processos narrativos que estão calcados nessas tópicas, faz levantar no âmbito da encenação discursiva um conjunto de saberes de crenças ligadas à emoção.

\subsection{ESPAÇO DE ESTRATÉGIAS}

A noção de estratégias discursivas repousa sobre a ideia de que o sujeito comunicante concebe, organiza e concretiza suas intenções de modo a produzir determinados efeitos sobre o sujeito interpretante, levando este último, em uma problemática de influência, a se identificar com o sujeito destinatário idealizado e construído pelo primeiro. Nesse sentido, se o sujeito comunicante deseja emocionar o seu interpretante, ele deve valer-se de uma mise en scène discursiva com uma visada patemizante. Em outras palavras, ele deve procurar gerar efeitos de sentido que suscite emoções em seu interpretante. Entretanto, como as estratégias são efeitos visados, nada garante que o interpretante sinta as emoções que o comunicante idealizou ao produzir o ato de linguagem. 
No que concerne ao nosso corpus, as estratégias de patemização ocorrem nos estratos linguageiros em que o ato de linguagem telenovelístico se apoia. Dessa forma, podemos dizer que há estratégias de ordem verbal e estratégias de ordem visual-fílmica ${ }^{5}$. Cada um desses tipos de estratégia mobiliza recursos do aparelho formal das materialidades significantes envolvidas na produção de sentido com o intuito de suscitar emoções no telespectador da telenovela (nosso TUi).

Como o ato telenovelístico é configurado por um contrato comunicacional que constrange as condições da troca, o sujeito comunicante, ao produzir estratégias de patemização nos estratos linguageiros considerados, não pode deixar de levar em conta tais restrições. Logo, há um espaço de estratégia disponibilizado pelas restrições contratuais que o sujeito considera ao procurar influenciar o seu interpretante no que tange ao processo de dramatização.

Nesse contexto, cumpre-nos destacar que a comunicação midiática ${ }^{6}$, segundo Charaudeau (2006) e Lochard e Soulages (1998), se realiza na tensão entre informar/explicar/entreter e captar o público a que ela se dirige. Isso ocorre pelo fato de as mídias se organizarem em função de uma lógica cívica, que é esta de informar/explicar/entreter o cidadão, e uma lógica econômica/comercial, que faz com que elas captem o maior número de pessoas de forma a sobreviver à concorrência de outras mídias no mercado de bens de consumo (CHARAUDEAU, 2006).

Como as estratégias de patemização são organizadas no discurso em função da margem de manobra disponibilizada pelas restrições contratuais, podemos compreender que tais estratégias, no que diz respeito ao ato de linguagem em estudo, procuram tocar o plano da captação. Nesse sentido, as estratégias de patemização encontradas em nosso corpus são encenadas no âmbito do ato de linguagem telenovelístico com o intuito de captar o público e garantir, por um lado, o consumo desse produto televisivo e, por outro lado, a audiência para a emissora.

A telenovela está organizada na divisão de blocos e na divisão de capítulos. Nesse sentido, as estratégias de patemização funcionam no sentido de garantir o consumo da telenovela não só durante toda a sua exibição (no caso de $O$ Astro, durante os seus 64 capítulos), mas também durante toda emissão, isto é, durante os momentos em que a história é interrompida de forma a dar espaço para a veiculação da publicidade televisiva.

\footnotetext{
${ }^{5}$ Poderíamos falar também de estratégias de ordem musical, já que a materialidade musical está em jogo no âmbito do ato de linguagem telenovelístico. Entretanto, neste trabalho, tal estrato não foi alvo de uma análise sistemática e, desse modo, não mencionamos as estratégias que ele poderia gerar.

6 Compartilhamos da perspectiva, proposta por Lochard e Soulages (1998), de que o contrato comunicacional de um gênero televisivo particular (como a telenovela) opera sob a forma de um jogo de encaixamento progressivo de diversos contratos. Neste jogo, o contrato da comunicação midiática geral é o nível mais alto desta hierarquia, enquanto o contrato telenovelístico é o nível mais baixo. Dessa forma, o contrato telenovelístico atualiza características dos demais contratos. Além do mais, para nós, a comunicação midiática é mais ampla e não se limita à informação. Tal como propõe Lochard e Soulages (1998), tal contrato realiza-se na tensão entre um fazer saber/compreender/agradar (visada de informação/explicação/emocional) e um fazer fazer (visada de incitação) - uma vez que o contrato de comunicação midiática produz um determinado objeto de informação, explicação ou entretenimento dentro de uma lógica cívica: informar/explicar/entreter o cidadão; e produz um objeto de consumo segundo uma lógica comercial: captar as massas para sobreviver à concorrência.
} 
Nas subseções abaixo apresentaremos as principais estratégias de patemização encontradas em nosso corpus tanto do ponto de vista do estrato verbal, quanto do ponto de vista do estrato visual-fílmico.

\subsubsection{ESTRATÉGIAS DE ORDEM VERBAL}

Em nosso corpus, o diálogo encenado é a forma enunciativa através da qual temos acesso ao estrato verbal. Diante disso, observamos que a patemização pode ocorrer através de duas principais estratégias: a) a descrição, em seu dizer, dos estados emotivos experienciados pelas personagens no interior da sequência; b) a qualificação das personagens no que diz respeito ao seu papel actancial no esquema narrativo central do plot selecionado.

No que concerne à primeira estratégia, consideremos o seguinte exemplo:

\section{EXEMPLO 1 - ESTRATÉGIAS DE PATEMIZAÇÃO (CAP02SEQ02)}

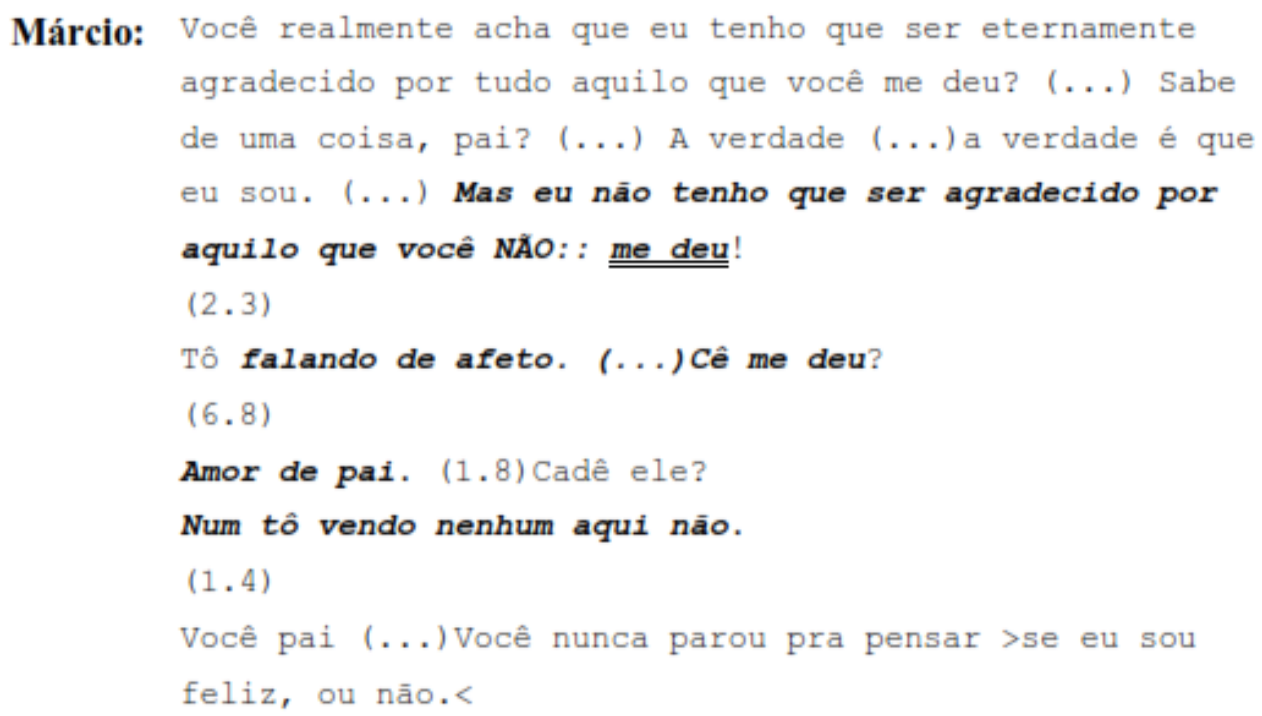

Neste exemplo, observamos que Márcio expressa sua revolta (e, por conseguinte, sua carência) pelas atitudes do seu pai, Salomão. Nesse exemplo, são empregadas palavras que descrevem de maneira transparente certas emoções ("afeto"; "amor de pai") e alguns enunciados patêmicos como "Mas eu não tenho que ser agradecido por aquilo que você não me deu" e "Num tô vendo ele aqui não". Nesse último caso, os enunciados embora não comportem palavras patemizantes, a situação de comunicação, bem como o processo narrativo em que tal sequência se apoia permite-nos observar a patemização. Assim, esse exemplo, de um modo geral, produz efeitos patêmicos através de um discurso explícito e direto. 
Esse tipo de estratégia é passível de ser apreendida não somente pela presença de palavras que expressem estados emotivos das personagens (embora isso também ocorra em nosso corpus), mas, sobretudo, pelo que está em jogo no interior da sequência analisada. Em outras palavras, é pela junção da temática da sequência e dos processos narrativos que nela se realizam que conseguimos interpretar determinadas palavras e enunciados como sendo patêmicos. Logo, a patemização está atrelada não só às condições contratuais da telenovela, mas ao que acontece no interior da sequência analisada.

Quanto à segunda estratégia de ordem verbal, as qualificações atribuídas às personagens no interior da diegese podem suscitar os efeitos que ora analisamos no destinatário na medida em que tais qualificações permitem criar uma espécie de "retrato" da figura no âmbito da história. Assim, uma figura qualificada negativamente (ou positivamente) ao longo dos vários capítulos em que a história se desenvolve possibilita propor um determinado saber sobre tal figura para o telespectador. Logo, ao vê-la em cena, o telespectador, de posse de suas competências, aciona tais saberes e mobiliza certas crenças a respeito da figura em questão.

Consideremos o exemplo 2, a seguir, para compreendermos melhor essa estratégia:

EXEMPLO 2 - QUALIFICAÇÃO DE SALOMÃO HAYALLA (CAP03SEQ05)

\author{
Clô: <Mo: : :nstro:!> (3.6) \\ Você é um monstro, Salomão. \\ Salomão: Eu fiz o que era preciso. \\ Clô: Internar seu filho? (2.4) ((chorando)) Dopá? (3.5) \\ Amarrar seu filho numa maca? Despachar numa \\ ambulâ:ncia (...) prum hospício? (1.2) Isso que era \\ preciso? \\ Salomão: ((suspira))

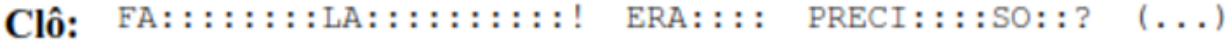 \\ HEIN? \\ Salomão: DEPOIS DO QUE ELE FEZ NA FESTA. \\ (1.5) \\ Clô: (chorando)) Ele falou a verda:: : de. (2.0) ((chorando)) \\ Botou pra fo:: :ra. (1.5) tudo $\circ$ que ele vem sentindo \\ desde criança. ((suspira)) Sua prepotê.i-incia. Sua \\ māo pesa: : : : : : da: : : (3.5) Você nunca fez um cari::nho \\ no menino.> (1.3) Sempre (..) critica:: : : : ndo. (..) \\ Sempre (..) ameaça: : : : ndo. Sempre puni:::::ndo. Sempre, \\ sempre $=$ \\ Salomão: Não é verdade. ((suspira)) (2.3) Ele sempre teve tudo $\circ$ \\ que quis.
}


Pelo exemplo 2, observamos que Clô qualifica Salomão como um “monstro". Essa qualificação permite criar um determinado saber a respeito da personagem Salomão Hayalla. Esse saber pode permitir que o telespectador tenha uma atitude de identificação (ou de não identificação) com a figura e, desse modo, o efeito patêmico pode ocorrer. Assim, tal efeito pode ser suscitado na medida em que essa qualificação é repetida ou reforçada por uma ou várias figuras ao longo dos diversos capítulos da telenovela, já que o telespectador, ao se identificar ou não com a figura, pode sentir uma determinada emoção (simpatia/antipatia) por essa mesma figura.

Logo, essa segunda estratégia ligada à suscitação de emoções no estrato verbal é produzida de maneira implícita e indireta. Ela depende não só do que é dito sobre uma determinada figura/personagem, mas também da atitude de identificação da parte do telespectador. Assim, ao se identificar com a figura, ele pode sentir uma determinada emoção e ser captado pela encenação discursiva. Com isso, o produto televisivo continua sendo consumido e a audiência garantida.

\subsubsection{ESTRATÉGIAS DE ORDEM VISUAL-FÍLMICA}

Os signos visuais-fílmicos (escala de planos/enquadramento, movimento de câmeras, transição de tomadas, moldura, etc.) são os elementos através dos quais podemos observar a patemização no interior do ato de linguagem telenovelístico.

Um ponto a ressaltar é que os efeitos patêmicos, em nosso corpus, não são obtidos pelo uso de certas categorias linguageiras do sistema da materialidade visual-fílmica, como, em princípio, poderíamos pensar. Nesse sentido, o uso de um determinado tipo de plano (o close-up, por exemplo), ou mesmo de um certo movimento de câmera (o zoomin, por exemplo), não faz com que ele engendre tais efeitos. Em nossas análises, observamos que os enunciados visuais são tidos como patêmicos se eles mostrarem algo tido como socialmente considerado socialmente como patêmico por meio de um certo tipo de mostração. Em outras palavras, a patemização, do ponto de vista do estrato visualfílmico, depende, por um lado, dos imaginários sociodiscursivos atrelados a certos fazeres sociais que são encenados no âmbito da telenovela (por exemplo, imaginários associados ao assassinato, à vingança, à humilhação); por outro lado, dos signos visuais utilizados durante a mostração desse fazer social.

Desse modo, os signos visuais não são emocionais por si só, mas são usados de forma a permitir que o efeito patêmico ocorra no interior da sequência: eles são usados de forma estratégica pelo sujeito enunciador para engendrar a patemização no interior da telenovela, podendo garantir, com efeito, a audiência e a captação do público.

Assim, quando dizemos, por exemplo, que um certo tipo de plano, como o primeiro plano, é patêmico, queremos dizer, com isso, que seu uso numa sequência determinada possibilita o engendramento desta categoria de efeitos de sentido no interior do ato de linguagem, uma vez que tal sequência mostra algum processo narrativo que, do ponto de vista sociocultural, está ligado a imaginários emocionais. 
Considerando o exposto, vejamos como a patemização se dá em nosso corpus no que diz respeito aos signos visuais-fílmicos. Em termos de escala de planos e variáveis proxêmicas, os gráficos 1 e 2 mostram-nos quantas vezes esses signos visuais são utilizados de forma patêmica e não patêmica em nosso corpus.

\section{Gráfico 1 - Escala de planos e patemização}

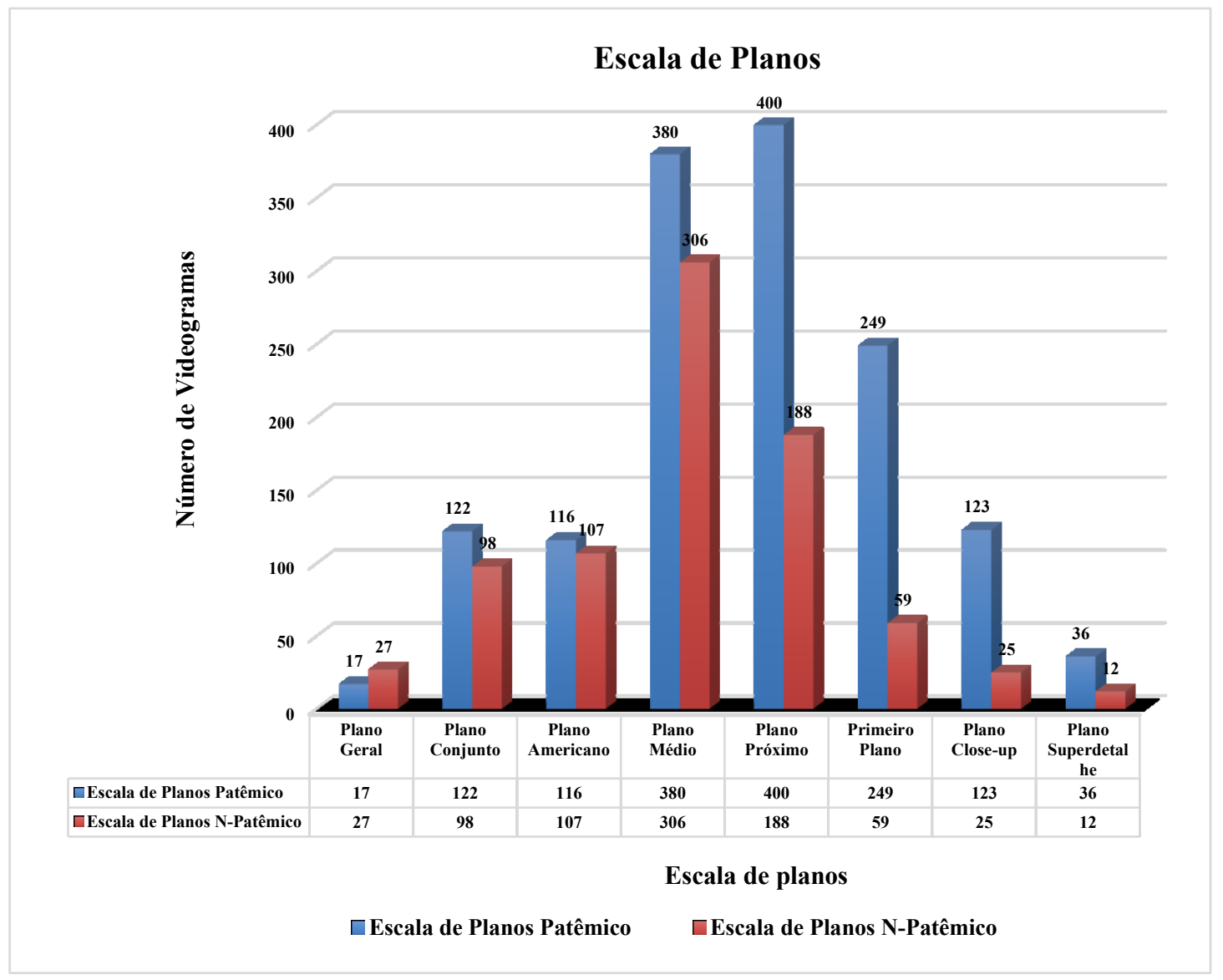

O gráfico 1 mostra-nos que os planos close-up e superdetalhe são, em nosso corpus, predominantemente patêmicos na medida em que, dos 196 videogramas decompostos nesses planos, 159 são usados de modo a produzir este tipo de efeito $(81,12 \%)$, ou seja, eles auxiliam no engendramento da patemização dentro das sequências em que eles aparecem. Por outro lado, o plano geral é predominantemente não patêmico, já que, dos 44 videogramas em que esse plano aparece, 27 são não patêmicos $(61,37 \%)$.

Essa predominância do uso desses dois planos nos dois polos da patemização (patêmico vs. não patêmico) merece um pouco de nossa atenção. O plano close-up, por enquadrar somente o rosto da personagem, possibilita um maior acesso ao estado emocional vivenciado pela personagem enquadrada nesse plano no interior da sequência. Com isso, o telespectador tem mais condições de perceber as expressões faciais das personagens e, desse modo, visualizar os estados emocionais vividos por ela. Caso ele se identifique com a figura actorial, o telespectador pode, por meio de uma atitude de projeção-identificação garantida pelo próprio dispositivo comunicativo, tomar partido em favor da personagem e, inclusive, sentir as emoções que essa última experimenta na diegese. Já o plano geral, por enquadrar a personagem em sua localização espacial, tem 
menos condições de ser usado de forma patêmica pelo sujeito enunciador. Porém, esse uso pode ocorrer, já que a patemização em nosso corpus não depende somente dos signos visuais e do que é dito, mas também do que ocorre no interior da sequência. Assim, se através de um plano conjunto, visualizamos uma ação narrativa que vai ao encontro da temática da sequência, o efeito patêmico pode ocorrer, conforme podemos visualizar no exemplo abaixo.

\section{Gráfico 2 - Variáveis proxêmicas e patemização}

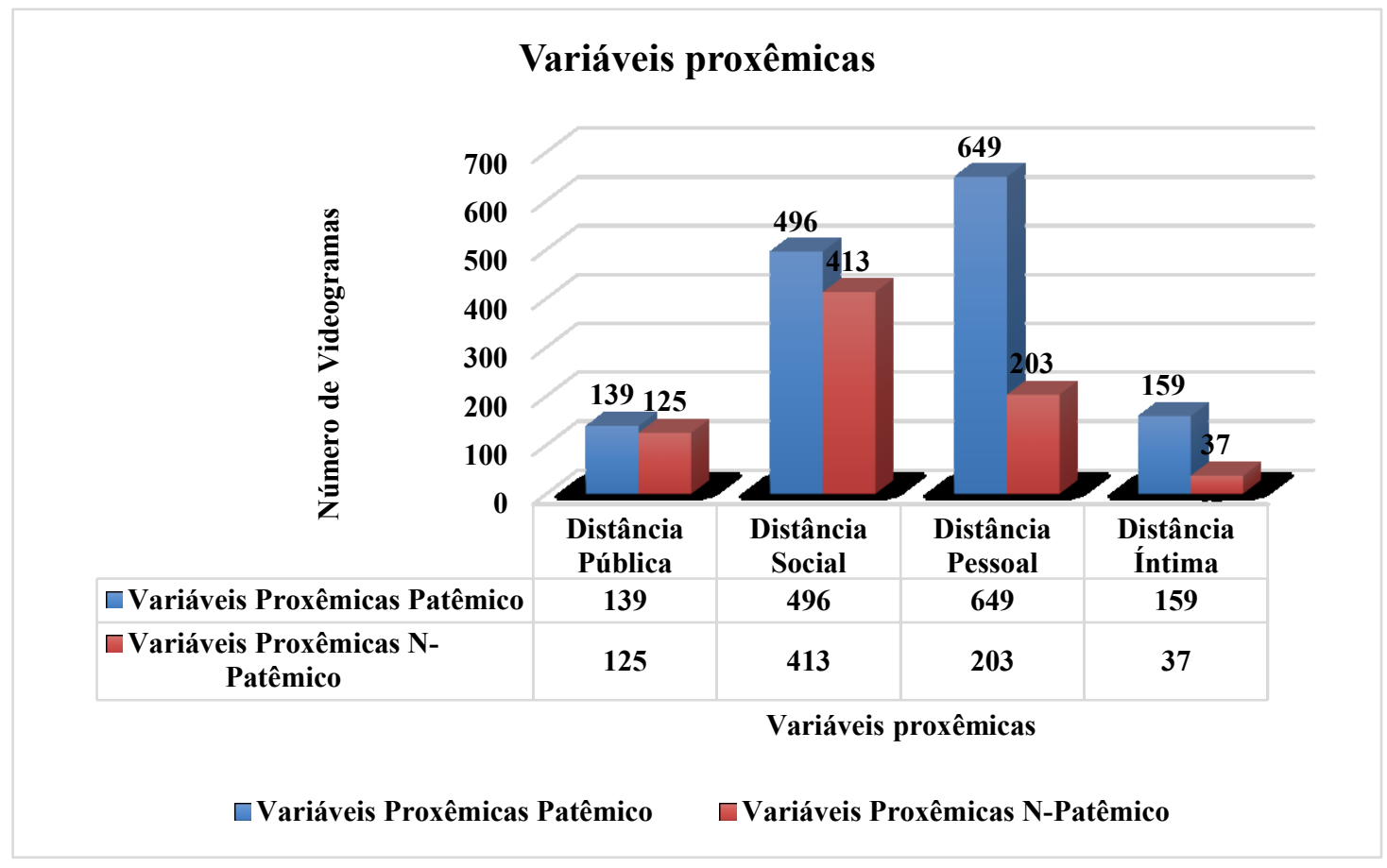

Essa predominância do uso desses dois planos nos dois polos da patemização (patêmico vs. não patêmico) merece um pouco de nossa atenção. O plano close-up, por enquadrar somente o rosto da personagem, possibilita um maior acesso ao estado emocional vivenciado pela personagem enquadrada nesse plano no interior da sequência. Com isso, o telespectador tem mais condições de perceber as expressões faciais das personagens e, desse modo, visualizar os estados emocionais vividos por ela. Caso ele se identifique com a figura actorial, o telespectador pode, por meio de uma atitude de projeção-identificação garantida pelo próprio dispositivo comunicativo, tomar partido em favor da personagem e, inclusive, sentir as emoções que essa última experimenta na diegese. Já o plano geral, por enquadrar a personagem em sua localização espacial, tem menos condições de ser usado de forma patêmica pelo sujeito enunciador. Porém, esse uso pode ocorrer, já que a patemização em nosso corpus não depende somente dos signos visuais e do que é dito, mas também do que ocorre no interior da sequência. Assim, se através de um plano conjunto, visualizamos uma ação narrativa que vai ao encontro da temática da sequência, o efeito patêmico pode ocorrer, conforme podemos visualizar no exemplo abaixo. 
EXEMPLO 3 - ESCALA DE PLANOS E PATEMIZAÇÃO (CAP15SEQ09)
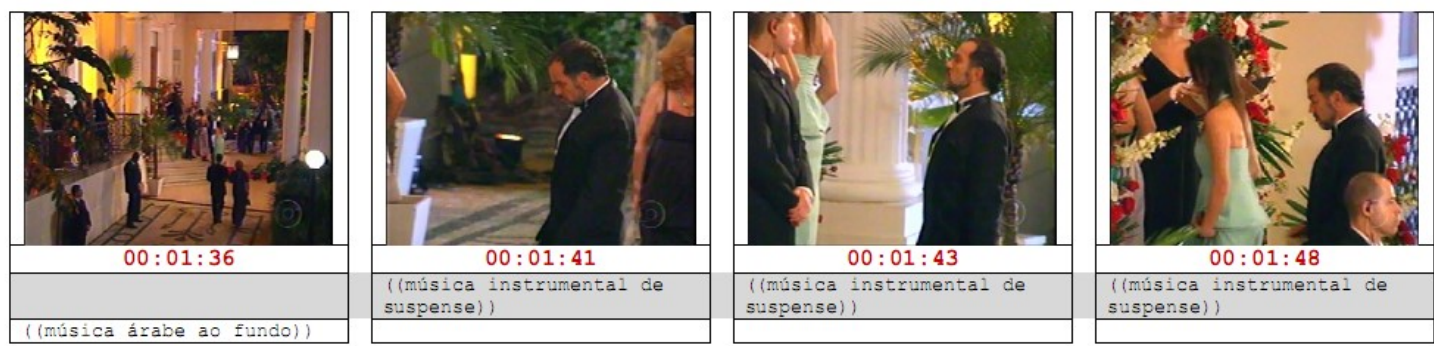

O primeiro videograma do exemplo 3 está em plano geral. Ele está sendo utilizado de modo patemizante na medida em que ele mostra a chegada de Neco à festa em que Salomão é morto. Como Neco, em sequências anteriores (como a CAP15SEQ08), expõe sua intenção de matar Salomão, sua chegada à mansão dos Hayalla (mostrada aqui pelo plano geral) pode suscitar no telespectador um determinado efeito patêmico, já que ele (o telespectador) sabe que Neco será um dos possíveis suspeitos do assassinato do empresário.

O mesmo é válido para os demais planos. Não são os planos em si que são patêmicos: eles podem ser utilizados estrategicamente pelo sujeito enunciador para engendrar este tipo de efeito. Essa finalidade patemizante atribuída aos planos vai ao encontro do que a sequência analisada mostra em termos de seus processos narrativos, bem como do universo temático (e dos imaginários sociodiscursivos, consequentemente) em que ela se apoia.

Entretanto, há alguns planos que têm mais chances de serem patêmicos pelo fato de enquadrar as personagens de uma determinada forma, como é o caso dos planos fechados, tais como o plano próximo, o primeiro plano, o plano close-up e o plano superdetalhe. Nesse caso, acreditamos que é possível observar uma espécie de potencialidade patêmica em alguns planos: há certos planos que são potencialmente mais patêmicos pela formatação que eles dão à imagem.

A patemização é um fenômeno retórico (portanto, discursivo) que se materializa em categorias linguageiras, de estratos variados, como no caso de nosso corpus. Não se trata de um fenômeno puramente semiótico, no qual uma categoria específica é sempre responsável por esse efeito discursivo. $\mathrm{O}$ que podemos afirmar, a partir da análise de nosso corpus, é que há uma potencialidade patêmica em certas categorias do estrato visual-fílmico, como é o caso plano close-up e do superdetalhe e, por conseguinte, da distância íntima.

No gráfico 2, observamos que a distância íntima é a variável proxêmica mais susceptível de acionar efeitos patêmicos no destinatário da telenovela, uma vez que ela permite um maior acesso aos estados emocionais das personagens. Em nosso corpus, dos 196 videogramas mostrados a essa distância, 159 videogramas $(81,12 \%)$ são patêmicos. Isso não significa, contudo, que, no interior de nosso corpus, toda distância íntima seja usada de forma a engendrar esta categoria de efeitos. Da mesma forma que a escala de planos, a distância em questão apresenta uma potencialidade patêmica. 
Dessa forma, outras distâncias, como a pública e a social, podem ser usadas pelo sujeito enunciador com uma finalidade patemizante. Como já apontamos, o uso dessas distâncias como patêmicas vai ao encontro do que acontece e do que é mostrado no interior da sequência.

No que diz respeito aos movimentos de câmera, consideremos o gráfico 3 abaixo.

\section{Gráfico 2 - Movimentos de câmera e patemização}

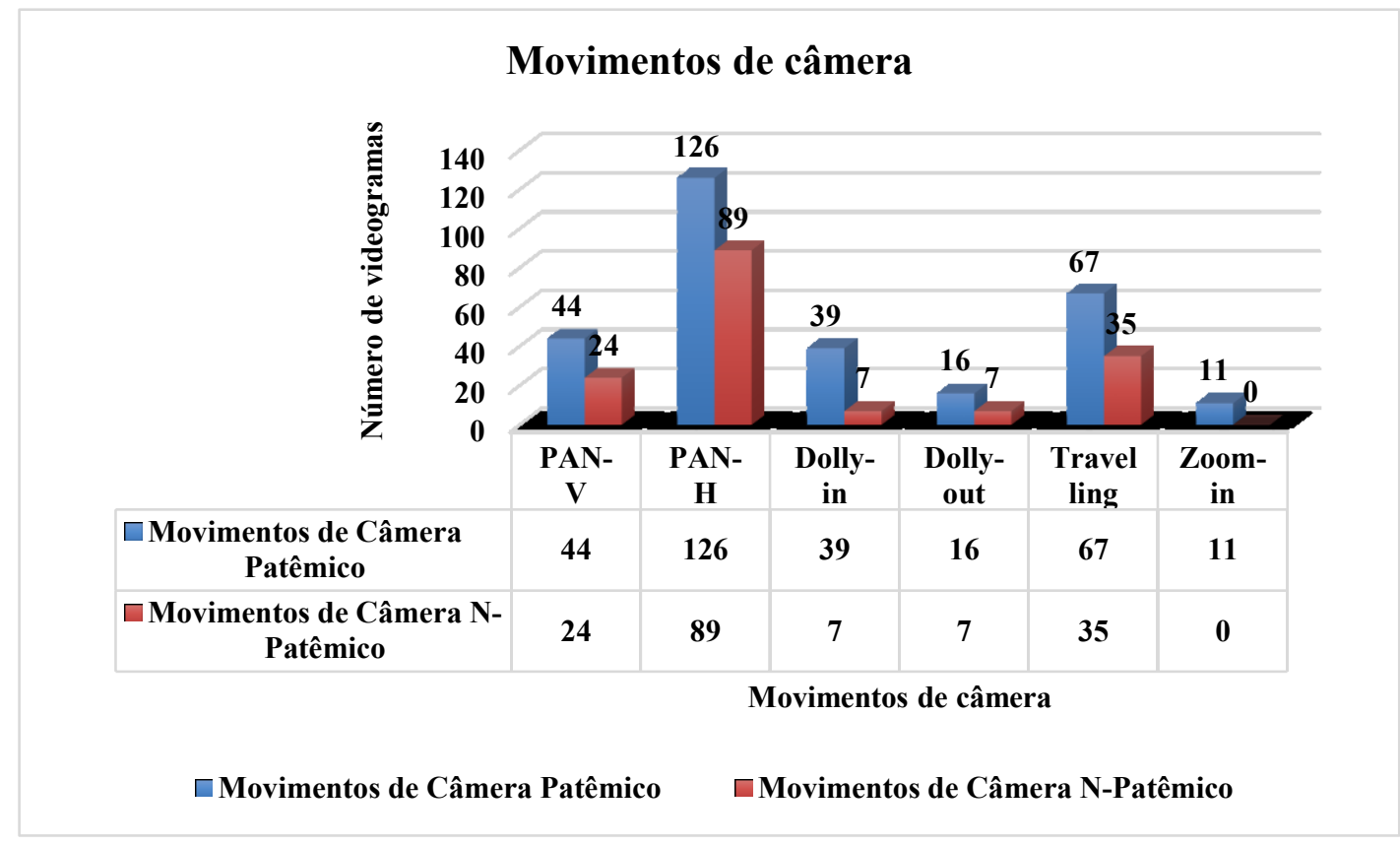

De acordo com o gráfico apresentado, dos 447 videogramas que representam os movimentos de câmera, 292 (65,38\%) são usados de forma patêmica. Em outras palavras, os movimentos de câmera auxiliam no engendramento de efeitos emocionais no âmbito da encenação discursiva que estamos analisando neste trabalho. $\mathrm{O}$ que nos chama a atenção é o fato de o movimento de Zoom-in ser, em nosso corpus, completamente patêmico (ele ocorre em 11 videogramas e todos eles foram usados para produzir este tipo de efeito). O zoom-in é um movimento óptico que traz a cena filmada para mais próximo do telespectador, fechando, com o isso, o enquadramento cênico. Ao realizar esse movimento, o telespectador tem um acesso maior à "intimidade" das personagens filmadas, possibilitando, desse modo, que venha a se identificar com os estados emocionais encenados por elas. $\mathrm{O}$ exemplo a seguir evidencia o exposto. 

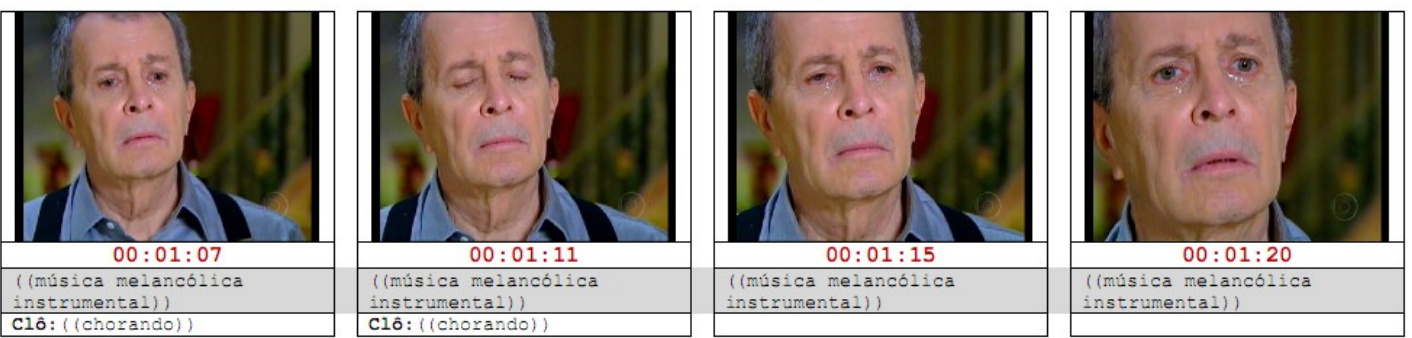

Os ângulos de filmagem também são signos visuais-fílmicos que auxiliam no engendramento da patemização em nosso corpus. O gráfico 4 a seguir evidencia que há a predominância do ângulo lateral horizontal (1825 videogramas - 80,57\%) em nosso corpus. A recorrência desse ângulo faz materializar, na enunciação, um tipo de jogo escópico denominado ponto de vista não-direcionado. Este ponto de vista não designa o telespectador enquanto tal, mas coloca este último em uma posição de observadortestemunha. Observando e testemunhando a cena mostrada pelo enunciador, o telespectador pode se identificar com o que ocorre no interior da sequência e, desse modo, sentir as emoções encenadas no âmbito da cena. Logo, o ângulo lateral horizontal e o ponto de vista não-direcionado são duas estratégias discursivas de patemização em nosso corpus.

Além dessa estratégia de ordem enunciativa demonstrada no parágrafo anterior, o uso dos ângulos de filmagem no âmbito do enunciado também permite engendrar efeitos emocionais. Assim como a escala de planos, as variáveis proxêmicas e os movimentos de câmera, os ângulos de filmagem possuem uma potencialidade patêmica que os faz serem patêmicos se um conjunto de condições forem reunidas durante a mostração. $\mathrm{O}$ gráfico 4 a seguir evidencia o uso patêmico dos ângulos de filmagem em nosso corpus

Chama-nos a atenção, nesse gráfico, o fato de o contre-plongée (câmera baixa) e o plongée (câmera alta) serem predominantemente patêmicos em nosso corpus. Dos 115 videogramas em que esses ângulos são utilizados, 83 (72,17\%) são patêmicos. Acreditamos que essa alta incidência se deva ao fato de esses ângulos materializarem o ponto de vista surreal. Conforme apontam Lochard e Soulages (1991), esse ponto de vista organizador dos jogos escópicos corresponde aos pontos de vista atípicos que não podem ser atribuídos a nenhum dos seres inscritos na cena televisiva. Pretendendo à ubiquidade, a câmera se designa, então, como um campo de visão. Assim, como a própria câmera é o campo de visão da imagem, ela é mais suscetível de produzir efeitos patêmicos, já que a câmera mostra o que ela quer mostrar. Além do mais, o contre-plongée e o plongée são muito utilizados, como apontam Aumont (2011), Aumont et al. (2011) e Stasheff et al. (1978), para produzir efeitos dramáticos nas cenas/sequências, seja no cinema ou mesmo na televisão. 


\section{Gráfico 3 - Ângulos de filmagem e patemização}

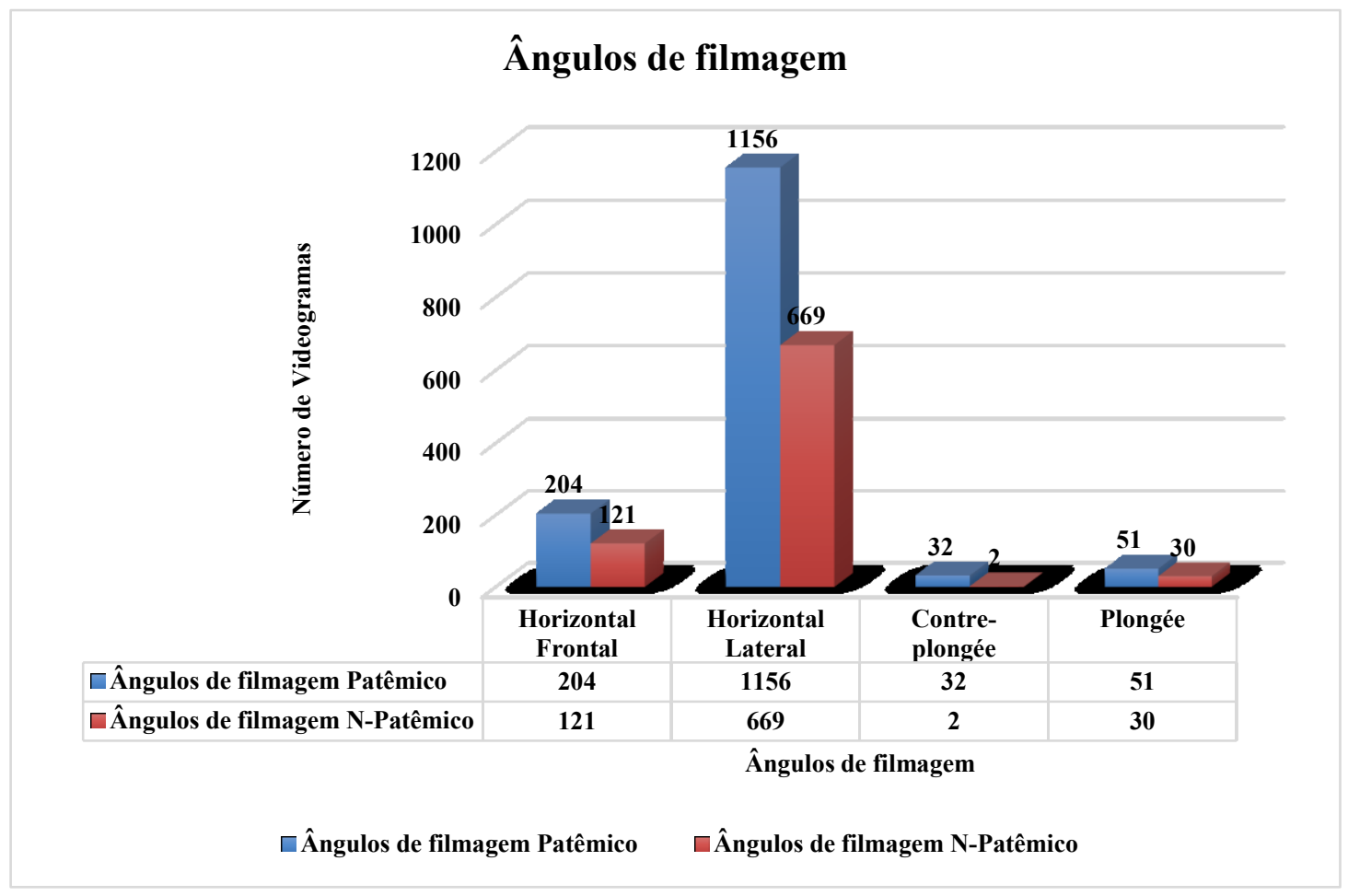

O exemplo a seguir, extraído de CAP15SEQ09, nos mostra o efeito dramático do contre-plongée em nosso corpus.

\section{EXEMPLO 5 - 0 CONTRE-PLONGÉE E A PATEMIZAÇÃO (CAP15SEQ09)}
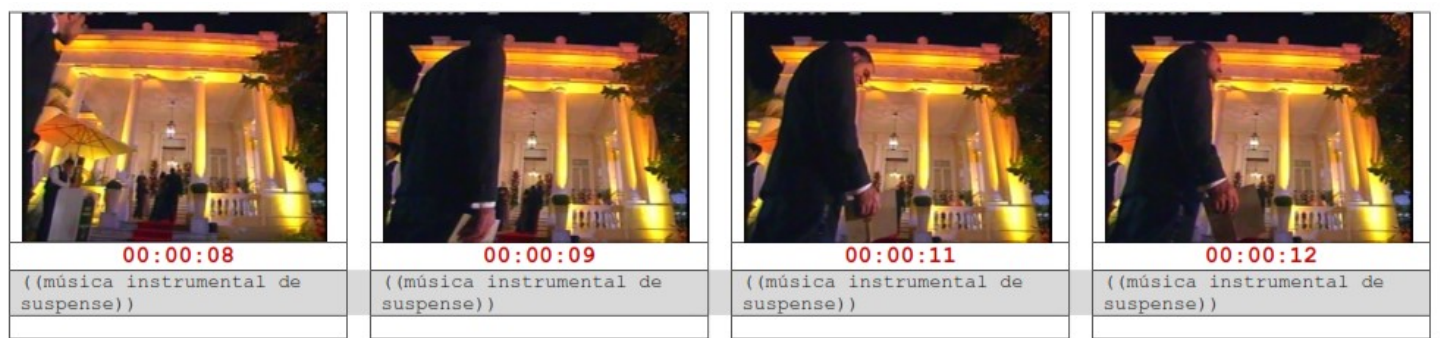

No contexto da sequência de que o exemplo 5 foi extraído, o contre-plongée é utilizado como uma forma de a câmera mostrar a ação de Neco ao entrar na mansão dos Hayalla durante a festa em que Salomão é assassinado. No capítulo 13, Neco declara que vai matar Salomão Hayalla, já que o empresário o humilhou. A chegada de Neco à mansão é, por si só, um indício de suspense. A posição da câmera na tomada evidenciada pelo exemplo acima, ao mostrar Neco - de baixo para cima - observando a mansão, reforça o suspense que sua chegada engendra e aguça a atenção do telespectador, que pode interpretar que Neco matará Salomão. Logo, o ângulo contre-plongée nesse caso é patêmico.

No que concerne às transições de tomada, observamos que elas também podem auxiliar na patemização. Constatamos que foram utilizados cinco tipos de transições de 
tomada em nosso corpus, a saber: o corte direto (934 recorrências), a fusão (6 videogramas), oflou (42 videogramas), o clareamento (6 videogramas) e o escurecimento (3 videogramas). Desses cinco, três tipos chamaram-nos a atenção pelo fato de engendrarem, de forma predominante, a patemização em nosso corpus. Consideremos o gráfico 5:

\section{Gráfico 4 - Transição de tomadas e patemização}

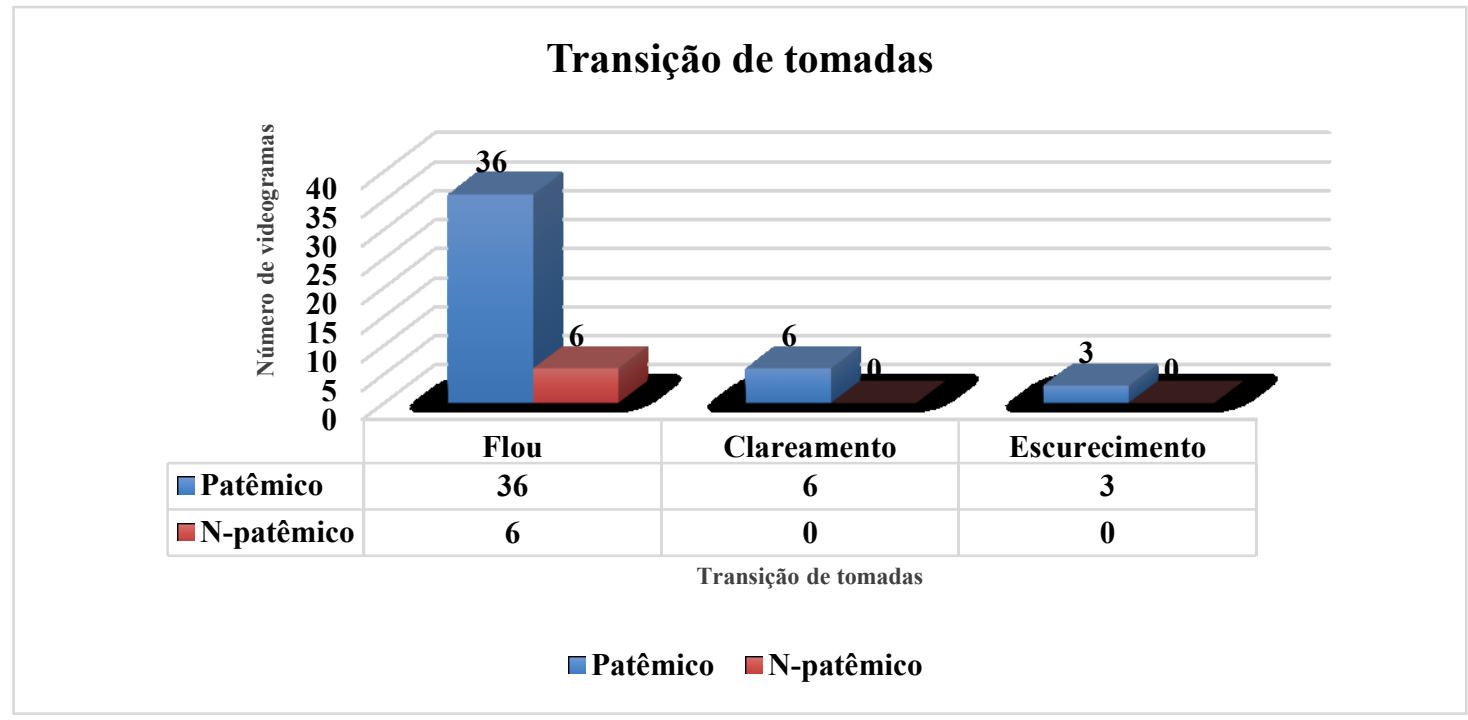

O gráfico 5 evidencia que o clareamento e o escurecimento são, em nosso corpus, completamente patêmicos. Consideremos o exemplo 6 para compreender melhor o exposto.

\section{EXEMPLO 6 - ESCURECIMENTO E PATEMIZAÇÃO (CAP02SEQ04)}
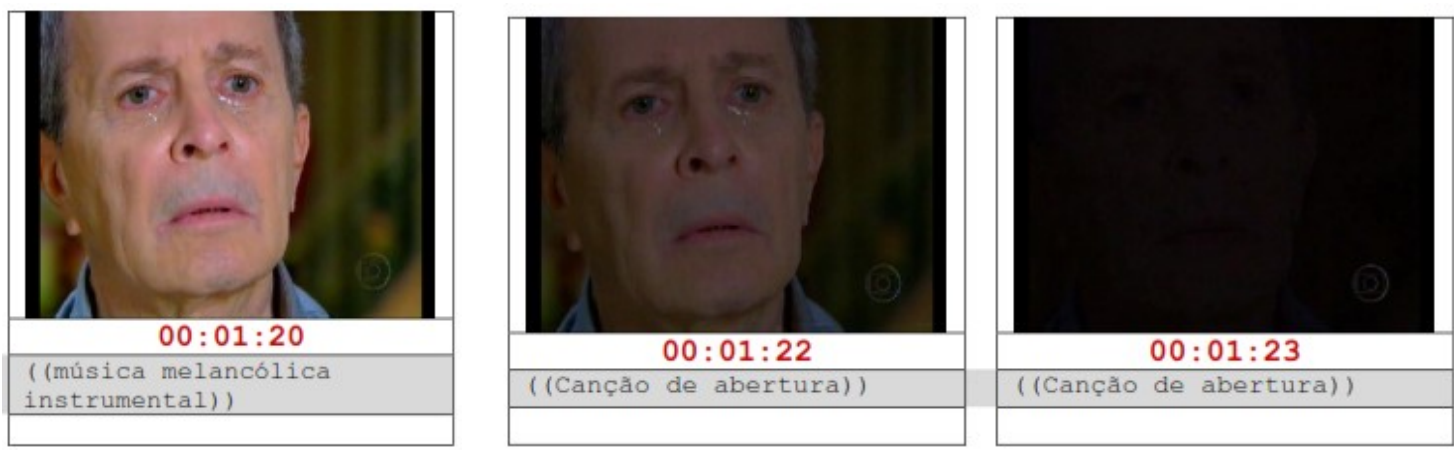

Pelo exemplo 6, observamos que à medida que a câmera aproxima o rosto de Salomão, através do zoom-in, a imagem se escurece gradativamente atingindo ao final o preto total. Essa transição é utilizada no final do capítulo 2 (e de outros capítulos da telenovela), marcando uma suspensão da história por um tempo longo, tal como nos apontam Stasheff et al. (1978). Desse modo, o uso desse tipo de transição é patêmica, já 
que, ao suspender a história no momento em que Salomão observa o filho sendo levado para a clínica de doentes mentais, o escurecimento deixa o telespectador, no mínimo, intrigado quanto ao desenrolar dos acontecimentos.

Um efeito análogo é obtido com o clareamento, tal como podemos observar no exemplo 7 .

\section{EXEMPLO 7 - CLAREAMENTO E PATEMIZAÇÃO (CAP0202)}
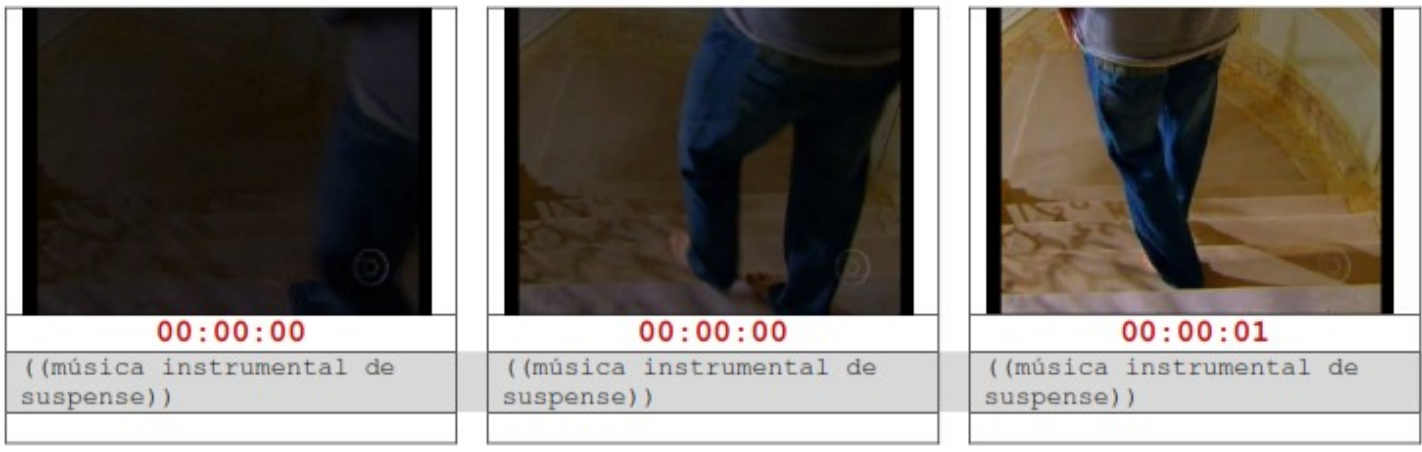

No caso do exemplo 7, que corresponde à sequência inicial do capítulo 2 de $O$ Astro, o uso do clareamento - uma transição que parte do preto total e chega à imagem nítida marca o início do capítulo e a retomada da história do ponto em que ela foi suspensa no capítulo anterior. Desse modo, o clareamento ativa a expectativa criada pelo gancho realizado ao final do primeiro capítulo, constituindo, para nós, uma estratégia de patemização.

O gráfico 5 também demonstra que o uso do flou em nosso corpus é predominantemente patêmico, na medida em que 36 videogramas $(85,71 \%)$, dos $42 \mathrm{em}$ que ele aparece, são usados de modo a engendrar este tipo de efeito. Como ele dota a imagem com uma espécie de "nuvem", criando uma atmosfera onírica, o uso do flou, em nosso corpus, introduz as cenas de flashback necessárias para o esclarecimento do crime, bem como retoma o desenrolar dos fatos da tomada anterior ao flou. Consideremos o exemplo 8:

\section{EXEMPLO 8 - 0 FLOU E A PATEMIZAÇÃO (CAP64SEQ10)}
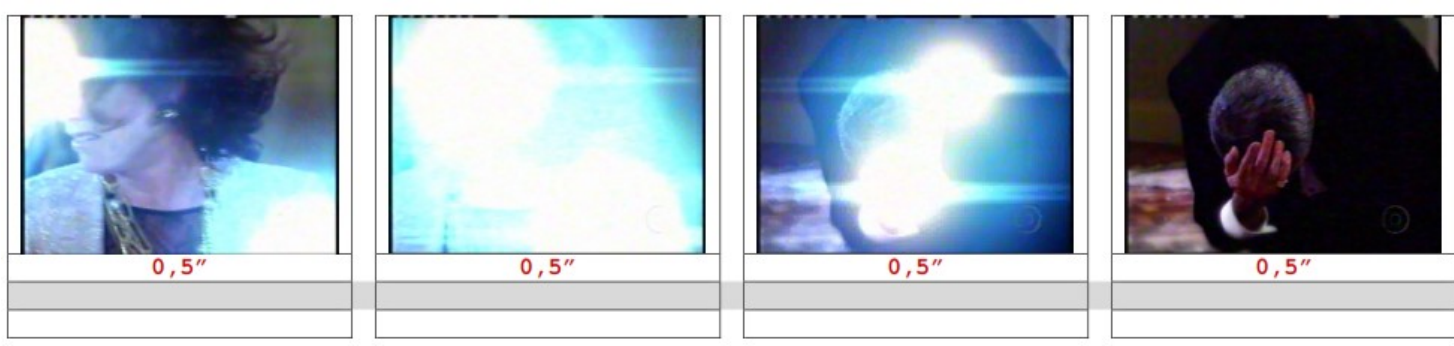

CORRÊA-ROSADO, Leonardo Coelho; MELO, Mônica Santos de Souza. Emoção e telenovela: um estudo das estratégias de patemização em $O$ Astro. Linguagem em (Dis)curso - LemD, Tubarão, SC, v. 17, n. 1, p. 89-116, jan./abr. 2017. 
No exemplo 8, visualizamos o flou transitando da tomada em que Clô confessa ser a assassina de Salomão para a tomada em que ela adentra o quarto com o intuito de matálo. Nesse contexto, o flou é utilizado de forma patêmica, já que ele lida com a expectativa ligada aos fatos apresentados pelo plot e com a possível expectativa do telespectador.

Outra estratégia observável em nosso corpus diz respeito ao uso da moldura, um signo visual que limita o que é mostrado. Essa estratégia é utilizada na sequência CAP15SEQ09. Consideremos o exemplo 9.

\section{EXEMPLO 9 - A MOLDURA E A PATEMIZAÇÃO (CAP15SEQ09)}
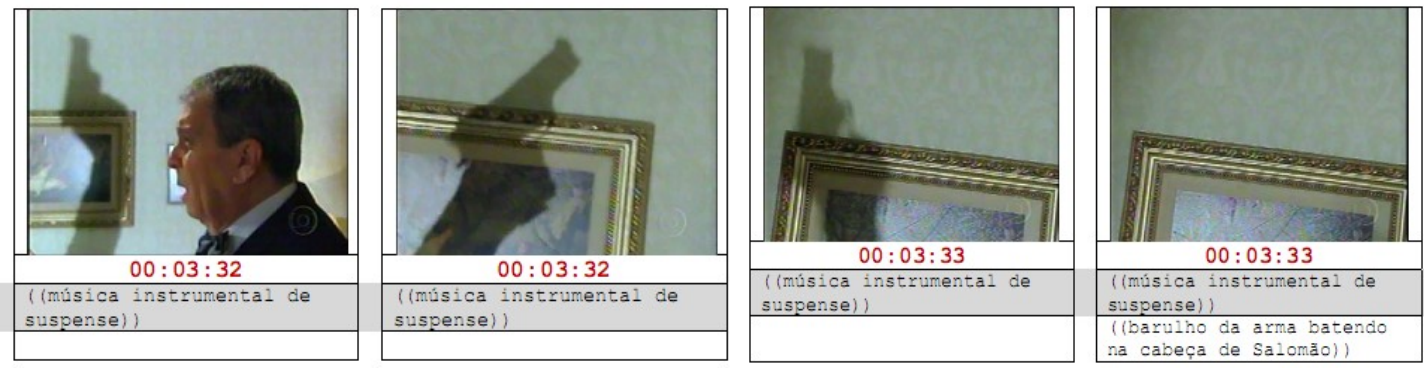

A sequência em questão mostra a personagem Salomão Hayalla sendo assassinada. O uso da moldura nesse fragmento é estratégico, na medida em que, ao limitar o campo da imagem, a moldura não permite que o assassino seja mostrado. Assim, cria-se um efeito de suspense que pode suscitar no telespectador certas emoções, já que ele passa a querer adivinhar quem matou o empresário. Com isso, a captação é uma mais vez acionada: cria-se no telespectador a vontade de assistir os demais capítulos para que possa juntar pistas e responder à questão: “quem, afinal, matou Salomão Hayalla?". Logo, não é a moldura em si que é patêmica: é o uso que é feito dela no interior da sequência que a torna uma estratégia de patemização.

Outra estratégia encontrada em nosso corpus tem a ver com o signo plástico da luminosidade. Embora nosso corpus apresente uma predominância da iluminação difusa, há momentos específicos em que uma iluminação que denominamos "escuro/sépia" aparece. Essa iluminação escurece o que está sendo mostrado no interior da sequência, e, ao mesmo tempo, utiliza um matiz acastanhado. Consideremos o exemplo 10:

\section{EXEMPLO 10 - A LUMINOSIDADE "ESCURO/SÉPIA" E A PATEMIZAÇÃO (CAP15SEQ09)}
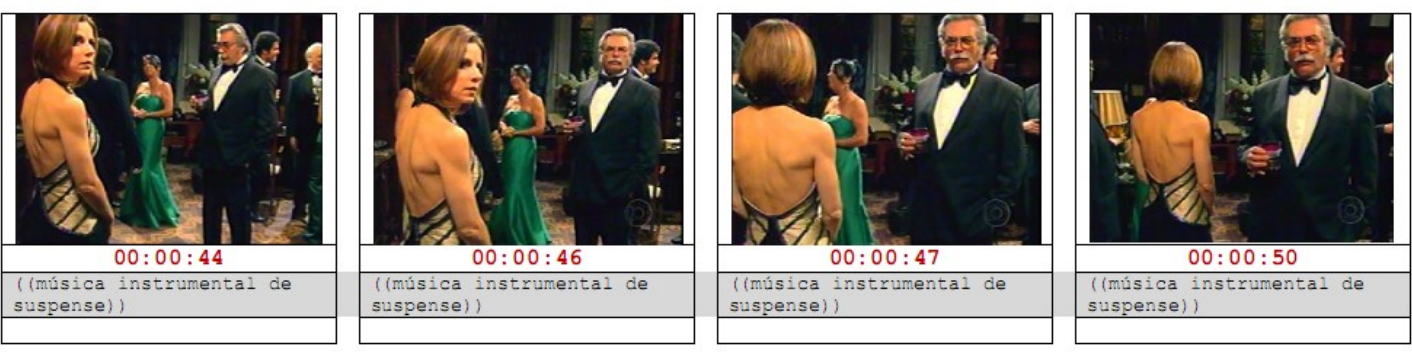

CORRÊA-ROSADO, Leonardo Coelho; MELO, Mônica Santos de Souza. Emoção e telenovela: um estudo das estratégias de patemização em $O$ Astro. Linguagem em (Dis)curso - LemD, Tubarão, SC, v. 17, n. 1, p. 89-116, jan./abr. 2017. 
Essa estratégia aparece somente em CAP15SEQ09 e CAP64SEQ10. Na primeira, ela é utilizada para mostrar o que aqueles que têm intenção de matar Salomão estão fazendo antes do assassinato. As cenas em que esse tipo de luminosidade é utilizado em CAP15SEQ09 sempre mostram as personagens realizando alguma coisa. Além do mais, essas cenas não são dialogadas e sim musicadas: há nelas uma música de suspense que cria toda uma atmosfera para elas. Logo, é exigido do telespectador um esforço de organizar sua lista de possíveis assassinos, indo ao encontro dos efeitos patêmicos que o enunciador visa a produzir.

Na segunda sequência (CAP64SEQ10), esse tipo de luminosidade é utilizado para realizar o flashback dos fatos, conforme podemos visualizar no exemplo 11.

\section{EXEMPLO 11 - LUMINOSIDADE E PATEMIZAÇÃO (CAP64SEQ10)}
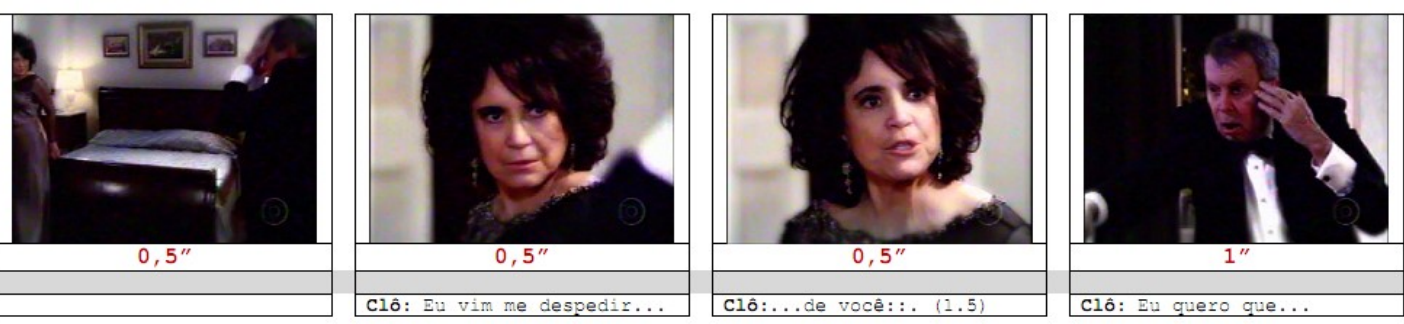

Através do recurso ao flashback, o telespectador fica sabendo sobre o que de fato ocorreu quando Salomão foi assassinado e, por conseguinte, os verdadeiros assassinos. Dessa forma, a luminosidade contribui de forma a dar uma atmosfera à sequência, atmosfera essa que suscita tópicas ligadas à questão do suspense e do assassinato. Assim, ela contribui, juntamente com os demais signos visuais-fílmicos, para encenar efeitos emocionais no interior do ato de linguagem que estamos analisando.

No que tange ao signo visual cor, em nosso corpus, há um uso intenso da cor preta - principalmente no figurino de algumas figuras actoriais durante a sequência do assassinato de Salomão -, como também de cores escuras, como o marrom, e de cores acinzentadas.

Em nossas análises, observamos que o preto pode ser tido como cor-informação, tal como propõe Guimarães (2004), uma vez que esta cor informa-nos a respeito da própria configuração do plot selecionado para o trabalho. Pastoureau (1997) aponta que a cor preta corresponde à cor do ódio, da tristeza e da melancolia e à cor da morte e dos ritos funerários. Como o plot selecionado para a pesquisa lida com os imaginários sociodiscursivos da morte e do assassinato, o uso do preto, sobretudo nas roupas dos suspeitos do assassinato de Salomão, vai ao encontro dessas conotações levantadas por Pastoureau (1997) a respeito dessa cor.

O exemplo 12 a seguir apresenta videogramas extraídos de CAP15SEQ09 e demonstra o uso do preto no figurino das personagens tidas como suspeitas pela morte de Salomão. 


\section{EXEMPLO 12 - A COR PRETA E A PATEMIZAÇÃO (CAP15SEQ09)}

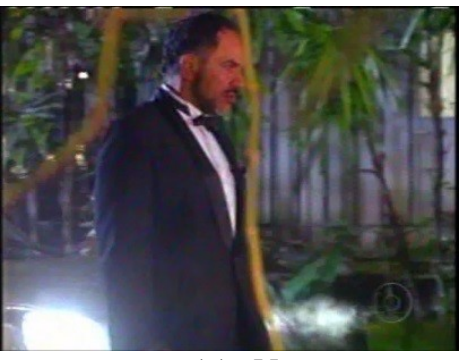

(a) Neco

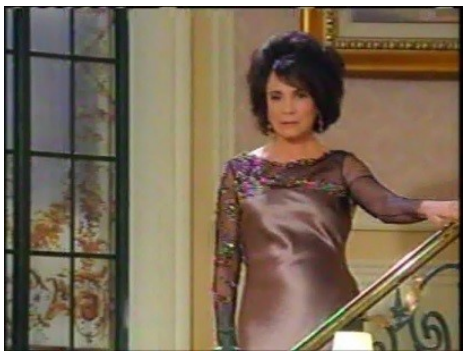

(d) Clô

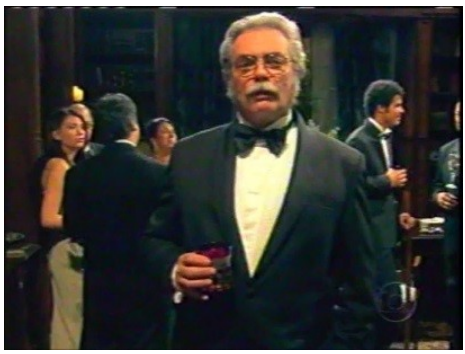

(g) Youssef

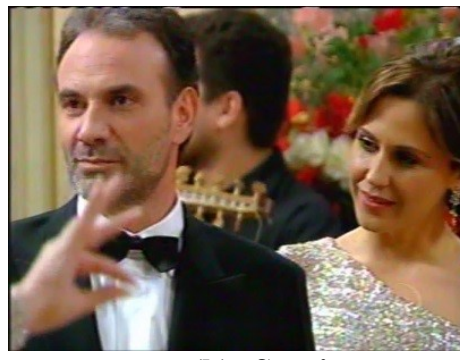

(b) Samir

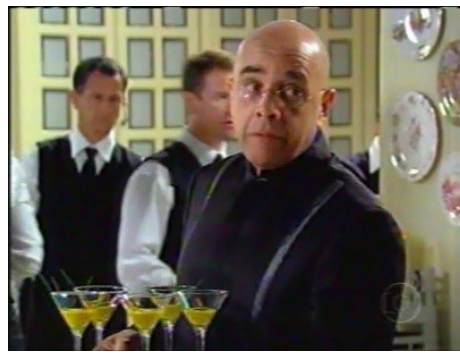

(e) Inácio

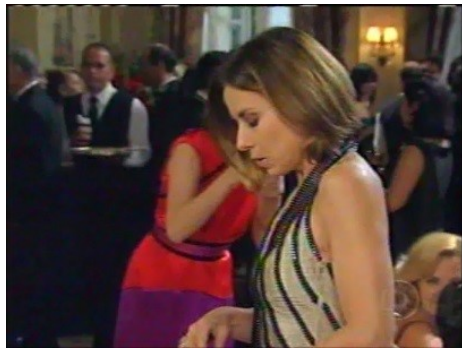

(h) Nádia

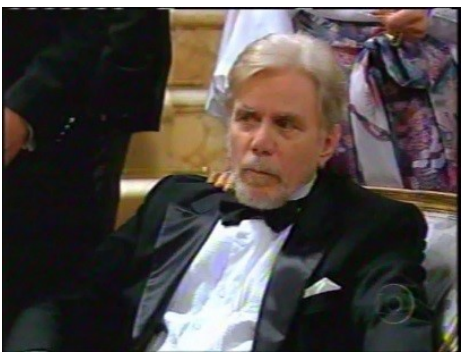

(c) Adolfo

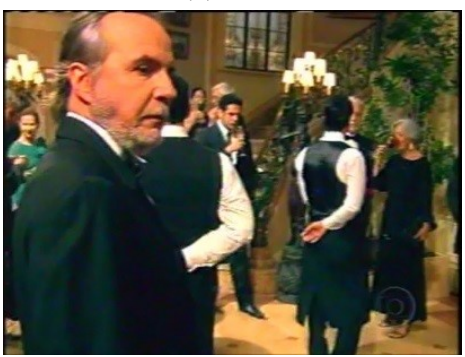

(f) Amin

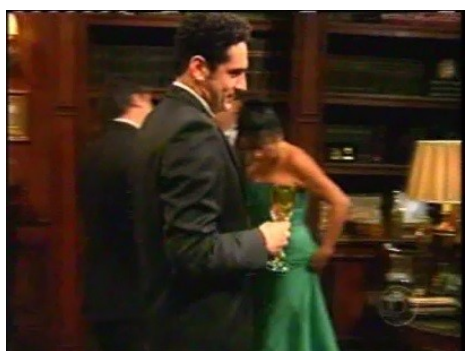

(i) Henri

Poderíamos pensar, em princípio, que o preto é utilizado para conotar elegância e requinte das personagens. Entretanto, ao comparar o figurino dos suspeitos com o dos demais personagens presentes na festa, vemos que essa interpretação não é completamente adequada, já que muitas personagens, como Beatriz e Jôsi, por exemplo, utilizam roupas de outras cores. Logo, o uso do preto no figurino dos suspeitos e no contexto da CAP15SE09 engendra o significado de ódio e morte que essa cor possui. Logo, o preto é utilizado de forma patêmica, já que vai ao encontro das tópicas suscitadas pelo nosso corpus.

As expressões faciais dos atores que compõem as personagens podem também funcionar como signos patêmicos, caso essas expressões demonstrem estados emocionais tidos como tal no âmbito de nosso corpus. Como tais expressões são parte da imagem do ator projetada na tela, elas correspondem a um tipo de signo icônico particular. $\mathrm{Na}$ verdade, podemos dizer que as expressões faciais são parte do signo icônico que representa uma determinada personagem. Consideremos o exemplo 13 a seguir. 

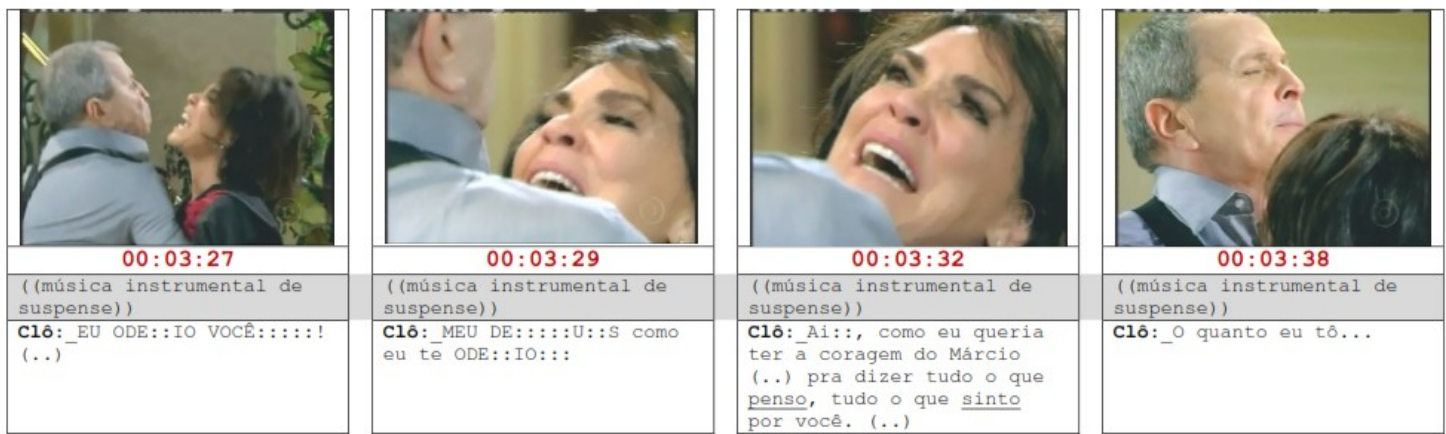

No exemplo 13, observamos a expressão de ódio/raiva que a personagem Clô Hayalla demonstra através de seu rosto. Essa emoção, materializada por meio desse signo icônico, é uma das emoções centrais de nosso corpus. No caso do exemplo, a raiva/ódio de Clô advém do fato de Márcio, o filho do casal, ter sido internado pelo próprio pai em uma clínica de doentes mentais. Sentindo piedade da situação do filho - que durante vários momentos da telenovela ela qualifica como "filho amado/adorado" - Clô externaliza, pois, o ódio para com o marido. Assim, a emoção demonstrada pelas expressões faciais de Clô vai ao encontro das tópicas suscitadas pelo nosso corpus, podendo ser considerada, com isso, um signo patêmico em nosso trabalho.

Situação similar à supracitada pode ser observada no exemplo 14.

\section{EXEMPLO 14 - EXPRESSÕES FACIAIS E PATEMIZAÇÃO (CAP64SEQ10)}
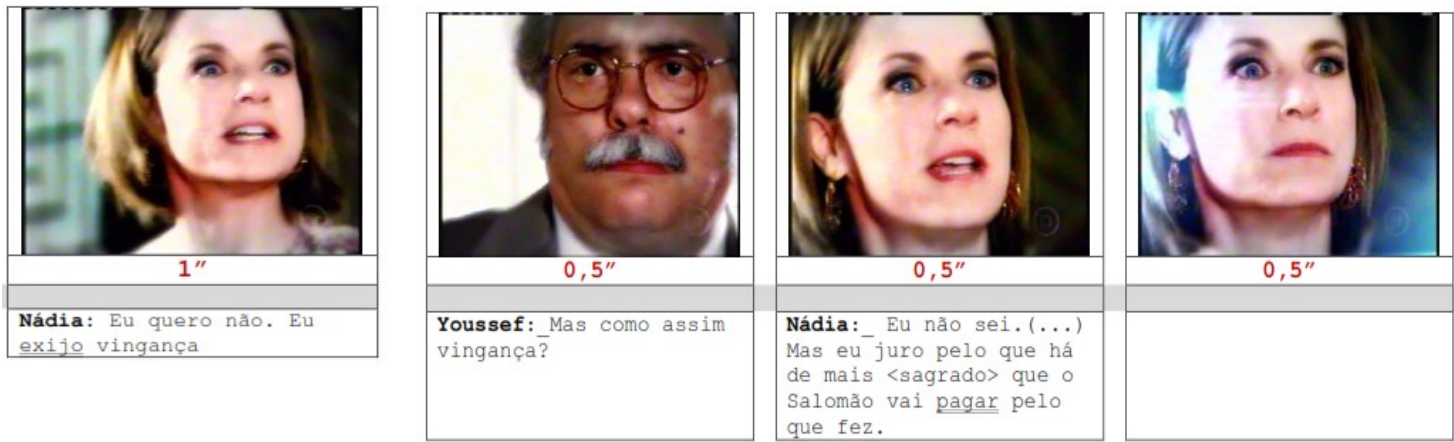

Neste exemplo, observamos uma expressão de raiva/ódio na face de Nádia Hayalla. Essa emoção é motivada pela humilhação que o casal, Youssef e Nádia, sofre durante uma reunião da diretoria do Grupo Hayalla. Salomão diz publicamente que Youssef é um castrado e que Nádia é uma mulher tão invejosa e tão preocupada com a vida alheia que não teve condições de gerar um filho. Ao ser informada pelo marido de que Salomão havia dito essas coisas a respeito dela numa reunião do Grupo, Nádia toma-se de ódio/raiva e afirma que irá vingar-se do cunhado. A vingança de fato se conclui, já que Nádia pede ao marido para matar Salomão com uma arma fornecida por ela, porém o máximo que Youssef consegue é deixar seu irmão tonto. 
Como o rosto do ator, no âmbito de uma produção ficcional televisual, é o principal veículo de expressão das emoções experimentadas pela personagem, ressaltamos que nem toda expressão facial, em nosso corpus, é patêmica. Há alguns casos de expressões faciais que não engendram patemização, como o evidenciado no exemplo 15.

\section{EXEMPLO 15 - EXPRESSÃO FACIAL NÃO PATÊMICA (CAP01SEQ01)}
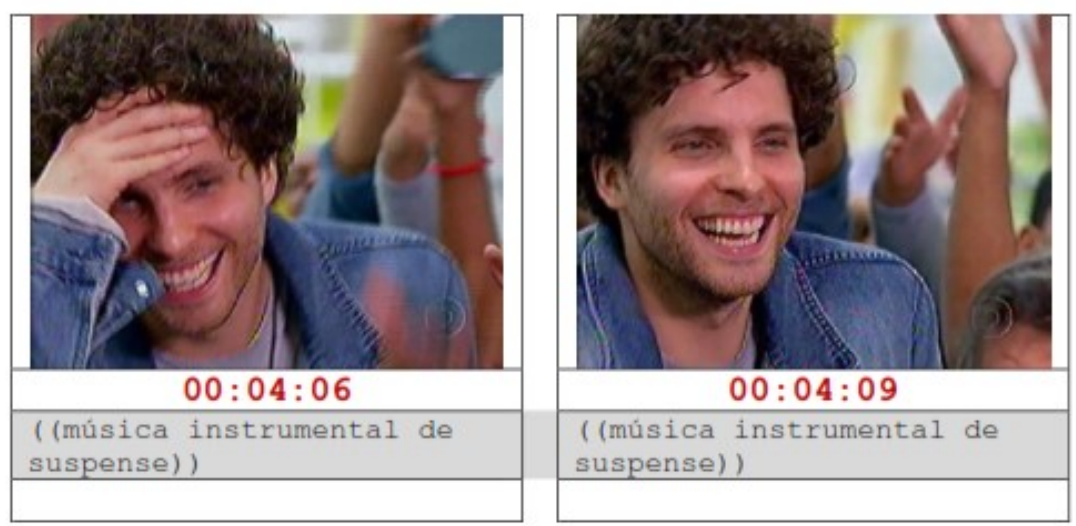

Assim, podemos dizer que as expressões faciais possuem, assim como outros signos visuais-fílmicos, uma potencialidade patêmica, já que elas expressam as emoções que as personagens vivenciam e, desse modo, podem suscitar no telespectador as mesmas emoções.

Portanto, os signos visuais-fílmicos engendram inúmeros efeitos patêmicos em nosso corpus. Eles, tal como alguns signos verbais, auxiliam na encenação da patemização de formas variadas, como apresentamos nos parágrafos anteriores.

\subsubsection{ESTRATÉGIAS DE ORDEM MUSICAL}

Embora não tenha sido alvo de uma análise sistemática em nosso trabalho, observamos que o estrato musical também auxilia no engendramento da patemização em nosso corpus.

Em quase todos os momentos de tensão das sequências analisadas, a música aparece como uma forma de "ambientar" a cena/sequência. Essa música é de ordem extradiegética, já que ela é inserida na sequência por meio da manipulação do enunciador e não faz parte do enunciado (a diegese), mas da enunciação.

Em nosso corpus, há a predominância de um tipo de música instrumental que cria suspense na história, alertando o telespectador a respeito do desenvolvimento do plot. Em outras palavras, a música em questão possui uma dupla função: por um lado, ela ambienta a cena através da criação de uma atmosfera de suspense, por outro lado, ela alerta o telespectador a respeito de que algo intrigante e inesperado vai acontecer adiante, seja na próxima cena/sequência, seja no próximo capítulo. Em nossas transcrições, denominamos 
essa música como música instrumental de suspense, tal como podemos visualizar no exemplo 16.

\section{EXEMPLO 16 - ESTRATO MUSICAL E PATEMIZAÇÃO (CAP15SEQ07)}
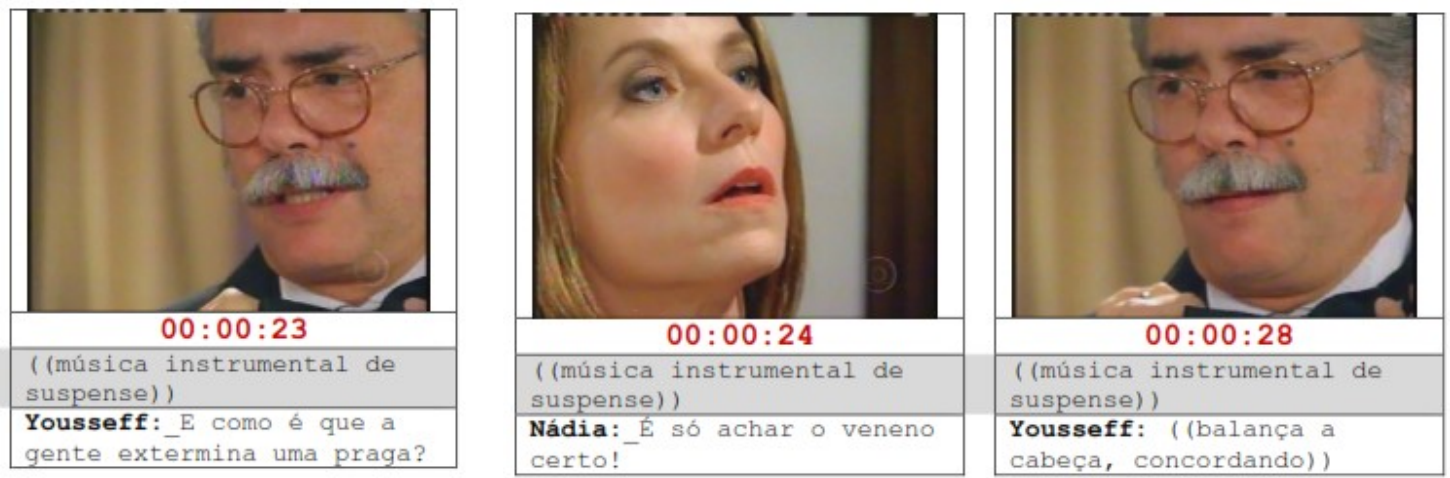

Nessa sequência Nádia e Youssef estão se aprontando para a festa na mansão dos Hayalla e, nesse momento, ambos deixam claro que planejam se vingar de Salomão. Nesse contexto, a música instrumental de suspense - que aparece desde o início da sequência - alerta o telespectador de que algo está por acontecer e de que tais figuras actoriais/personagens podem ser os assassinos de Salomão.

No exemplo 17, a seguir, também visualizamos o mesmo efeito em relação à música instrumental de suspense advinda do estrato musical.

\section{EXEMPLO 17 - ESTRATO MUSICAL E PATEMIZAÇÃO (CAP15SEQ09)}
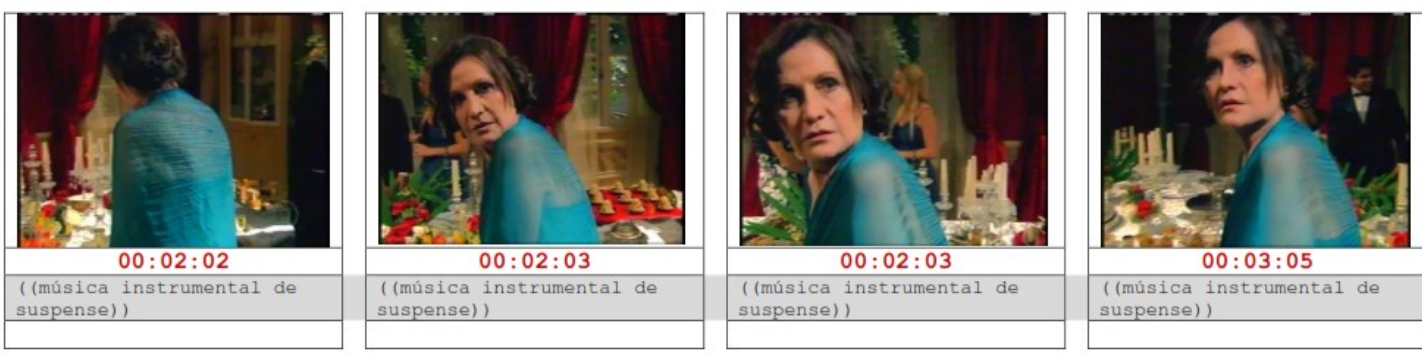

Como essa música instrumental de suspense possui tanto uma função de ambientação, quanto de alerta, compreendemo-la, em nosso corpus, como correspondendo a um signo que engendra patemização no discurso analisado. Desse modo, a música em questão funciona concomitantemente com os demais signos patêmicos avindos seja do estrato verbal, seja do estrato visual-fílmico. Logo, em termos de patemização, podemos dizer que ela reforça, através de um procedimento retórico que poderíamos denominar "ancoragem musical", as estratégias dos outros estratos linguageiros. Ela reforça, portanto, os efeitos emocionais engendrados pelo estrato visualfílmico e pelo estrato verbal. 
O presente artigo apresentou as principais estratégias de patemização encontradas na análise de nosso corpus, considerando os estratos verbal e visual-fílmico. De modo geral, concluímos que a patemização na telenovela estudada ocorre em função da necessidade de captação do telespectador, bem como em função da própria organização narrativa da história. Nesse sentido, a história de $O$ Astro é construída de forma a manter o suspense do plot "Quem matou Salomão Hayalla?" e garantir a "presença" do telespectador ao longo dos capítulos.

Como uma categoria de efeito visado, a patemização está relacionada a duas importantes condições: a) o processo narrativo que organiza a sequência; b) a identificação-projeção do telespectador nesse processo. Todavia, sendo um efeito visado, nada garante que o telespectador "sinta" o estado emocional suscitado. Assim, para observar a questão dos efeitos produzidos, sugerimos que pesquisas ligadas à questão da recepção devem ser desenvolvidas.

\section{REFERÊNCIAS}

AUMONT, J.; MARIE, M. Dicionário teórico e crítico de cinema. Trad. Eloisa Araújo Ribeiro. 5. ed. Campinas/SP: Papirus, 2010.

AUMONT, J. et al. A estética do filme. Trad. Marina Appenzeller. 8. ed. Campinas/SP: Papirus Editora, 2011.

CHARAUDEAU, P. Langage et discours - éléments de sémiolinguistique (théorie et pratique). Paris: Hachette, 1983.

Une analyse sémiolinguistique du discours. Langages, Paris, v. 29, n. 117, p. 96-111, 1995.

Grammaire du sens et de l'expression. Paris: Hachette, 1992.

. Une problématisation discursive de l'émotion. À propos des effets de pathémisation à la

télévision. In: DOURY, M.; TRAVERSO, V. (Org.) Les émotions dans les interactions. Arci/ Presses Universitaires de Lyon: 2000. p. 125-155.

. Visadas discursivas, gêneros situacionais e construção textual. Tradução de Renato de Melo. In: MACHADO, I. L.; MELLO, R. (Org.). Gêneros: reflexões em análise do discurso. Belo Horizonte: NAD/FALE/UFMG, 2004. p. 13-41.

Discurso das mídias. Tradução de Angela M. S. Corrêa. São Paulo: Contexto, 2006.

Les stéréotypes, c'est bien. Les imaginaires, c'est mieux. In: BOYER, H. (Org.). Stéréotypage, stéréotypes: fonctionnements ordinaires et mises en scène. Paris: Harmattan, 2007.

Pathos et discours politique. In: RINN, M. (Org.). Émotions et discours - L'usage des passions dans la langue. Rennes/França: Presses Universitaires de Rennes, 2008.

A patemização na televisão como estratégia de autenticidade. In: MENDES, E.; MACHADO, I. $\overline{\mathrm{L}}$ (Org.). As emoções no discurso. Campinas/SP: Mercado de Letras, 2010. v. 2. p. 23-56.

LOCHARD, G.; SOULAGES, J. Faire voir la parole. In: CHARAUDEAU, P. La télévision, les débats culturels « Apostrophes ». Paris: Didier, 1991. p. 141-167.

La communication télévisuelle. Paris: Armand Colin, 1998.

MELO, M. S. S. Estratégias discursivas em publicidades de televisão. 2003. 302f. Tese (Doutorado em Estudos Linguísticos) - Faculdade de Letras, Universidade Federal de Minas Gerais, Belo Horizonte, 2003.

PASTOUREAU, M. Dicionário das cores do nosso tempo: simbólica e sociedade. Trad. Maria José Figueiredo. Lisboa: Editorial Estampa, 1997.

STASHEFF, E. et al. O programa de televisão: sua direção e produção. Tradução de Luiz Antonio Simões de Carvalho. São Paulo/SP: EDU: Ed. da Universidade de São Paulo, 1978. 
Recebido em: 01/07/16. Aprovado em: 30/12/16.

Title: Emotion and soap opera: a study of patemization strategies in $\mathrm{O}$ Astro

Authors: Leonardo Coelho Corrêa-Rosado; Mônica Santos de Souza Melo

Abstract: the present study aims to describe and analyze the patemization strategies in a plot, in other words, on a trajectory of narrative action, in the soap opera $O$ Astro, from 10 audiovisual sequences representing this plot. The soap opera was broadcasted by Globo from 12 July to 28 October 2011 at the time of 23 hours. The survey was conducted from the theoretical and methodological framework of Semiolinguistics Theory (CHARAUDEAU 1983, 1992, 1995, 2006). For the analysis of patemization, we stratify the object of study in two strata: verbal and visual-filmic. The results showed that, as a discursive strategy, patemization touches the plan of capitation: the media instance wants to thrill the viewer in order to keep him/her captive during the period of the telenovela airing.

Key-words: Semiolinguistics. Soap opera. Emotion.

Título: Emoción y telenovela: un estudio de las estratégias de patemización en $\mathrm{O}$ Astro Autores: Leonardo Coelho Corrêa-Rosado; Mônica Santos de Souza Melo

Resumen: Este trabajo tiene el objetivo de describir y analizar las estrategias de patemización en un plot, es decir, en una trayectoria de acción narrativa, en la telenovela $\mathrm{O}$ Astro, desde 10 secuencias audiovisuales que representan este plot. La novela fue exhibida por la Red Globo entre 12 de julio y 28 de octubre de 2011 en el horario de las 23 horas. La investigación fue realizada desde la estructura teórica y metodológica de la Teoría Semiótica y lingüistica (CHARAUDEAU, 1983, 1992, 1995, 2006). Para el análisis de la patemización, estratificamos el objeto de estudio en dos estratos: verbal y visual-filme. Los resultados evidenciaron que, como estrategia discursiva, la patemización toca el plan de la captación: la instancia mediática desea emocionar el telespectador con el objetivo de mantenerlo captivo durante la exhibición de la telenovela.

Palabras-clave: Semiótica y lingüística. Telenovela. Emoción.

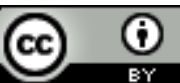

Este texto está licenciado com uma Licença Creative Commons Atribuição 4.0 Internacional.

CORREA-ROSADO, Leonardo Coelho; MELO, Mônica Santos de Souza. Emoção e telenovela: um estudo das estratégias de patemização em $O$ Astro. Linguagem em (Dis)curso - LemD, Tubarão, SC, v. 17, n. 1, p. 89-116, jan./abr. 2017. 